\title{
Apolipoprotein E and Apolipoprotein E Receptors: Normal Biology and Roles in Alzheimer Disease
}

\author{
David M. Holtzman ${ }^{1}$, Joachim Herz ${ }^{2}$, and Guojun $\mathrm{Bu}^{3}$ \\ ${ }^{1}$ Department of Neurology, Alzheimer's Disease Research Center, Hope Center for Neurological Disorders, \\ Washington University School of Medicine, St. Louis, Missouri 63110 \\ ${ }^{2}$ Departments of Molecular Genetics, Neuroscience, and Neurology and Neurotherapeutics, \\ University of Texas, Southwestern, Dallas, Texas 75390-9046 \\ ${ }^{3}$ Department of Neuroscience, Mayo Clinic, Jacksonville, Florida 32224 \\ Correspondence: holtzman@neuro.wustl.edu
}

Apolipoprotein $\mathrm{E}(A P O E)$ genotype is the major genetic risk factor for Alzheimer disease (AD); the $\varepsilon 4$ allele increases risk and the $\varepsilon 2$ allele is protective. In the central nervous system (CNS), apoE is produced by glial cells, is present in high-density-like lipoproteins, interacts with several receptors that are members of the low-density lipoprotein receptor (LDLR) family, and is a protein that binds to the amyloid- $\beta$ (A $\beta$ ) peptide. There are a variety of mechanisms by which apoE isoform may influence risk for AD. There is substantial evidence that differential effects of apoE isoform on AD risk are influenced by the ability of apoE to affect $A \beta$ aggregation and clearance in the brain. Other mechanisms are also likely to play a role in the ability of apoE to influence CNS function as well as AD, including effects on synaptic plasticity, cell signaling, lipid transport and metabolism, and neuroinflammation. ApoE receptors, including LDLRs, Apoer2, very low-density lipoprotein receptors (VLDLRs), and lipoprotein receptor-related protein 1 (LRP1) appear to influence both the CNS effects of apoE as well as A $\beta$ metabolism and toxicity. Therapeutic strategies based on apoE and apoE receptors may include influencing apoE/A $\beta$ interactions, apoE structure, apoE lipidation, LDLR receptor family member function, and signaling. Understanding the normal and disease-related biology connecting apoE, apoE receptors, and AD is likely to provide novel insights into AD pathogenesis and treatment.

lzheimer disease (AD), specifically the late-
common form of AD (LOAD), is the most
older than 60 years of age. Although mutations
in the genes PS1, PS2, and APP cause less com-
mon forms of early-onset, autosomal dominant familial $\mathrm{AD}(\mathrm{FAD})$, these cases represent $<1 \%$ of $\mathrm{AD}$. In addition to the genes that cause FAD, LOAD also has a strong genetic component. Although several susceptibility genes for $\mathrm{AD}$ have been reported, by far the strongest genetic risk factor for LOAD is apolipoprotein

Editors: Dennis J. Selkoe, Eckhard Mandelkow, and David M. Holtzman

Additional Perspectives on The Biology of Alzheimer Disease available at www.perspectivesinmedicine.org

Copyright (C) 2012 Cold Spring Harbor Laboratory Press; all rights reserved; doi: 10.1101/cshperspect.a006312

Cite this article as Cold Spring Harb Perspect Med 2012;2:a006312 
D.M. Holtzman et al.

$\mathrm{E}(A P O E)$ genotype, with the $\varepsilon 4$ allele being an $\mathrm{AD}$ risk factor and the $\varepsilon 2$ allele being protective relative to the prevalent $\varepsilon 3$ allele (Corder et al. 1993; Strittmatter et al. 1993a). Strong evidence suggests a major mechanism by which apoE influences $\mathrm{AD}$ and cerebral amyloid angiopathy (CAA) is via its effects on $\mathrm{A} \beta$ metabolism (Kim et al. 2009a; Castellano et al. 2011). Current understanding of apoE biology in the CNS and how apoE/A $\beta$ interactions are relevant to $\mathrm{AD}$ will be reviewed in the first section. There are several apoE receptors that are members of the LDLR family (Fig. 1). Some of these receptors, such as LDLR and LRP1, influence apoE levels (Fryer et al. 2005a; Liu et al. 2007). Others, such as Apoer2 and VLDLR, although apoE receptors, are also receptors for other ligands such as the neuromodulatory signaling protein
Reelin, which plays an important role in neurodevelopment and synpatic function. These receptors are involved in neural signaling and tau phosphorylation, and there is evidence that apoE can counteract some of the neurotoxicity caused by $A \beta$. Apoer2 and VLDLR will be reviewed in the second section. LDLR and LRP1 are important receptors for apoE in the brain that regulate CNS apoE levels. Although LDLR has no known ligand other than apoE in the CNS, LRP is somewhat unique in that it has multiple ligands, binds to both APP and $\mathrm{A} \beta$, and influences APP and A $\beta$ metabolism. LDLR and LRP1 will be reviewed in the third section. Although there are currently no apoEbased therapies for $\mathrm{AD}$, given the effects of apoE and apoE receptors on both $A \beta$ and CNS development and function, a variety of

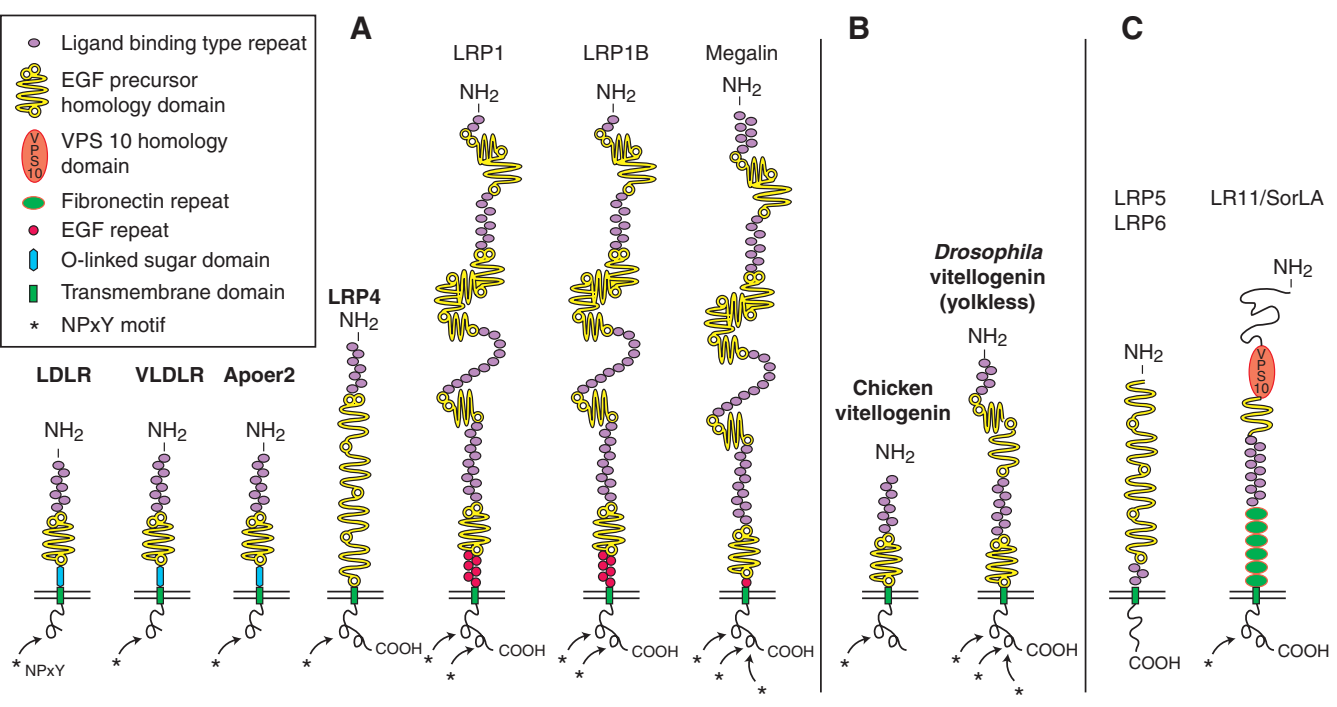

Figure 1. The low-density lipoprotein (LDL) receptor gene family. (A) The core LDL receptor gene family as it exists in mammalian species. These family members are characterized by one or more ligand-binding domains, epidermal growth factor (EGF), homology domains consisting of EGF repeats and YWTD propeller ( $\beta$-propeller) domains involved in $\mathrm{pH}$-dependent release of ligands in the endosomes, a single transmembrane domain and a cytoplasmic tail containing at least one NPxY motif. The latter represents both the endocytosis signal as well as a binding site for adaptor proteins linking the receptor to intracellular signaling pathways. Furthermore, LDLR, VLDLR, and Apoer2 carry an O-linked sugar domain. (B) Equivalent receptors that are structurally and functionally distinct family members in nonmammalian species. $(C)$ A subgroup of functionally important, but more distantly related family members that share some, but not all, of the structural requirements of the "core members." In addition, they could also contain domains, e.g., vacuolar protein sorting (VPS) domains, which are not present in the core family. (From Dieckmann et al. 2010; reprinted, with permission, from Walter de Gruyter GmbH (C 2010.) 
apoE/apoE receptor-based approaches will be discussed.

\section{ApoE: POTENTIAL ROLE IN AD}

\section{Neurobiology of ApoE}

The human apoE protein is a 299 amino acid glycoprotein that is expressed by several cell types, but with highest expression in the liver and in the CNS (Mahley 1988). In the brain, apoE is expressed predominantly by astrocytes but also by microglia (Fig. 2) (Pitas et al. 1987; Grehan et al. 2001). Under certain conditions, such as after excitotoxic injury, some neurons appear to be able to synthesize apoE (Xu et al. 1999; Xu et al. 2006). Under physiological conditions, apoE is present in lipoprotein particles (Fig. 2). Although it is present in lipoproteins of different size classes in plasma, in the CNS, it is the most abundantly produced apoprotein and is secreted by glial cells in nascent high-density lipoprotein (HDL)-like particles (Pitas et al. 1987; DeMattos et al. 2001) that are discoidal in shape and contain phospholipids and cholesterol. ApoE is also present in cerebrospinal fluid (CSF) at a concentration of $\sim 5 \mu \mathrm{g} / \mathrm{ml}$, in spherical particles that are similar to glial-secreted HDL, except that they also contain a cholesteryl ester core ( $\mathrm{LaDu}$ et al. 1998). Although apoE-containing lipoproteins may play a role in reverse cholesterol transport as well as in cholesterol and lipid delivery, their role in CNS lipid and cholesterol homeostasis is not yet clearly defined. As in the periphery, apoE functions as a ligand in receptor-mediated endocytosis of lipoprotein particles in the CNS. In vitro studies have shown that cholesterol released from apoE-containing lipoprotein particles is used to support synaptogenesis (Mauch et al. 2001) and the maintenance of synaptic connections (Pfrieger 2003). Although there is some in vitro (Nathan et al. 1994; Holtzman et al. 1995) and in vivo (Masliah et al. 1995; Poirier 2003) data suggesting that apoE can play a role in neuronal sprouting after injury, whether apoE plays a major role in supporting synaptogenesis and maintenance of synaptic connections in vivo in the uninjured brain has not yet been proven. For example, several studies have shown that the brain of apoE knockout mice, for the most part, appears normal in the absence of injury (Anderson et al. 1998; Fagan et al. 1998). Moreover, no overt cognitive defects have been reported in humans with genetic ApoE deficiency. In addition to apoE, several other apolipolipoproteins are present in the CNS, the most abundant being apoAI and apoJ, also called clusterin. ApoE in the CNS is derived from the CNS; the same appears to be true for clusterin. In contrast, apoAI in CNS is derived from the periphery (SorciThomas et al. 1988). Whether apoAI and clusterin play a role in CNS lipid metabolism, or in normal brain function, is not clear. Genetic deficiency of either protein in humans or mice does not result in an obvious CNS phenotype (Schaefer et al. 1982; McLaughlin et al. 2000). Interestingly, single-nucleotide polymorphisms in clusterin have been shown to be a risk factor for AD (Harold et al. 2009; Lambert et al. 2009). The mechanism for this is unclear, although animal model data have shown that clusterin strongly influences $A \beta$ aggregation and toxicity in vivo (DeMattos et al. 2002; DeMattos et al. 2004).

\section{Genetic, Clinical, and Biomarker \\ Observations on Relationship of ApoE and AD}

The human apoE gene contains several singlenucleotide polymorphisms (SNPs) distributed across the gene (Nickerson et al. 2000). The most common three SNPs lead to changes in the coding sequence and result in the three common isoforms of apoE: apoE2 (cys112, cys158), apoE3 (cys112, arg158), and apoE4 (arg112, arg158). Although the three common isoforms differ by only one or two amino acids at residues 112 or 158 , these differences alter apoE structure and function (Mahley et al. 2006). In regard to the connection between apoE and $\mathrm{AD}$, apoE was found to colocalize with amyloid plaques in the early 1990s (Namba et al. 1991; Wisniewski and Frangione 1992). After that, the $\varepsilon 4$ allele of the $A P O E$ gene was discovered to be a strong genetic risk factor for AD (Corder et al. 1993; Strittmatter 
D.M. Holtzman et al.

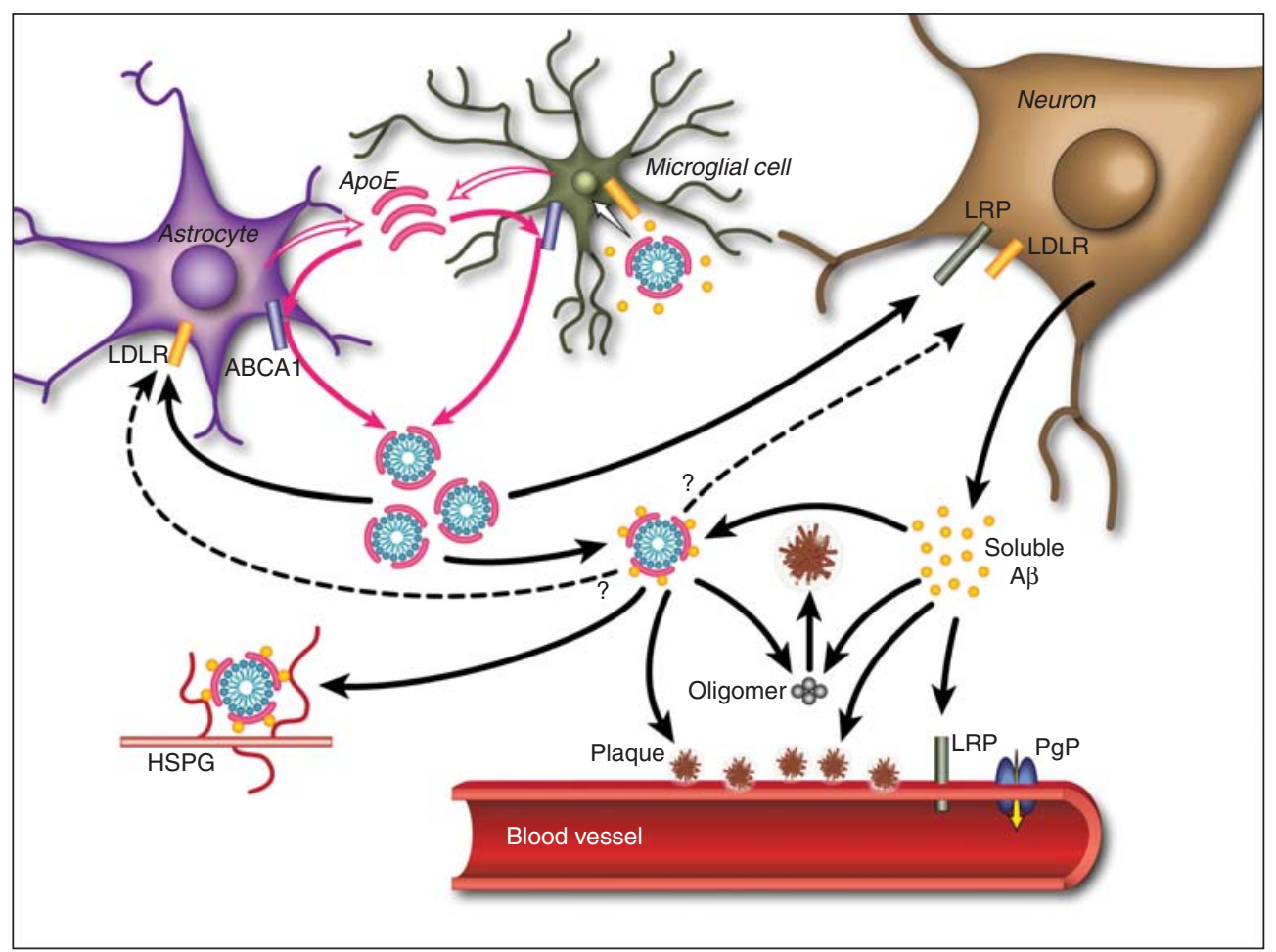

Figure 2. Pathways by which apoE and $A \beta$ interact in the brain. ApoE is primarily produced by both astrocytes and microglia and is subsequently lipidated by ABCA1 to form lipoprotein particles. In the extracellular space, lipidated apoE binds to soluble $A \beta$ in an isoform-dependent pattern $(E 2>E 3>E 4)$ and influences the formation of parenchymal amyloid plaques and transport of $A \beta$ within the $C N S$. ApoE is endocytosed into various cell types within the brain by different members of the LDL receptor family, including LDLR and LRP1. ApoE may also facilitate the cellular uptake of $A \beta$ through the endocytosis of a complex of apoE-containing lipoprotein particles bound to $A \beta$ in a manner that likely depends on the isoforms and its level of lipidation. Furthermore, apoE has been shown to directly enhance both the degradation of $A \beta$ within microglial cells and the ability of astrocytes to clear diffuse A $\beta$ deposits (Koistinaho et al. 2004; Jiang et al. 2008). A $\beta$ associated with apoEcontaining lipoprotein particles may also be retained within the CNS through their binding to heparin sulfate proteoglycan (HSPG) moieties present in the extracellular space (Mahley and Rall 2000). At the blood-brain barrier $(\mathrm{BBB})$, soluble $\mathrm{A} \beta$ is predominantly transported from the interstitial fluid into the bloodstream via LRP1 and P-glycoprotein (Cirrito et al. 2005; Zlokovic 2008). ApoE has been shown to slow the transport of $\mathrm{A} \beta$ across the $\mathrm{BBB}$ in an isoform-dependent manner (E4 > E3 > E2) (Bell et al. 2007; Ito et al. 2007; Deane et al. 2008). In addition, apoE can influence the pathogenesis of CAA in an amyloid protein precursor (APP)transgenic mouse model, with apoE4 increasing the amount of vascular plaques in comparison to apoE3 (Fryer et al. 2005b). (From Kim et al. 2009; reprinted, with permission, from Elsevier (C) 2009.)

et al. 1993a). Since then, numerous studies have confirmed that the $\varepsilon 4$ allele is the strongest genetic risk factor for both $\mathrm{AD}$ and $\mathrm{CAA}$, or a combination of both disorders (Schmechel et al. 1993; Greenberg et al. 1995; Bertram et al. 2007). As compared to individuals with no $\varepsilon 4$ alleles, the increased risk for $\mathrm{AD}$ is approximately threefold in people with one $\varepsilon 4$ allele and $\sim 12$-fold in those with two $\varepsilon 4$ alleles. The odds ratio for $\varepsilon 4$ versus $\varepsilon 3$ alleles by metaanalysis of multiple studies is 3.68 as of June 2011 (www.alzgene.org). Importantly, the $\varepsilon 2$ allele of apoE is associated with a lower risk for AD (Corder et al. 1994; Farrer et al. 1997) with an odds ratio of $\varepsilon 2$ versus $\varepsilon 3$ of 0.62 as of June 2011 (www.alzgene.org). 
Evidence of a Key Role for ApoE on A $\beta$ Metabolism in AD Pathogenesis

In vitro and in vivo data including data in humans and animal models suggests that the physical interaction of apoE with $\mathrm{A} \beta$ plays an important role in $\mathrm{AD}$ and $\mathrm{CAA}$ pathogenesis (Fig. 1). It was first proposed that apoE was an $\mathrm{A} \beta$-binding protein in the brain that induces a pathological $\beta$-sheet conformational change in $A \beta$ (Wisniewski and Frangione 1992). Pathological studies showed a positive correlation between plaque density and $\varepsilon 4$ allele dose in AD patients at autopsy (Rebeck et al. 1993; Schmechel et al. 1993). Although some studies reported conflicting findings (Benjamin et al. 1995; Heinonen et al. 1995), a large autopsy study strongly suggested that $\varepsilon 4$ dosage is associated with increased neuritic plaques in $\mathrm{AD}$ (Tiraboschi et al. 2004). If the effect of apoE4 is to accelerate the average onset of $\mathrm{A} \beta$ deposition in the brain, an expectation would be that middle-aged individuals at risk to develop $\mathrm{AD}$ in the future who are still cogntively normal would have larger amounts of $A \beta$ deposition in the brain. This has now been shown to be the case as evidenced by amyloid-imaging studies with Pittsburgh compound B as well as CSF studies using CSF A $\beta 42$ in which a decrease has been shown to indicate brain amyloid deposition. Cognitively normal apoE4-positive middle-aged and elderly individuals are much more likely to have brain amyloid (Reiman et al. 2009; Morris et al. 2010) and low CSF A 342 (Sunderland et al. 2004; Morris et al. 2010) than apoE4-negative individuals. Further, apoE2-positive individuals rarely develop fibrillar $A \beta$ as defined by a positive amyloidimaging scan (Morris et al. 2010).

Whereas human data supports the idea that apoE isoforms result in differential susceptibilty to $A \beta$ aggregation in the brain, animal studies utilizing genetically modified mice that develop $A \beta$ deposition and express human apoE isoforms show more directly that human apoE isoforms have a strong effect on the time of onset of $A \beta$ aggregation as well as the amount, location, and conformation of $\mathrm{A} \beta$ in the brain. Early studies with APP-transgenic
Apolipoprotein E and Apolipoprotein E Receptors

(Tg) mice that develop $A \beta$ deposition in the brain (PDAPP and Tg2576 models) showed that when these mice were crossed with $\operatorname{apoE}^{-/-}$mice, there was less $\mathrm{A} \beta$ deposition and a virtual abolishment of true amyloid plaques, plaque-associated neuritic dystrophy, CAA, and CAA-associated microhemorrhage in the absence of apoE (Bales et al. 1997; Bales et al. 1999; Holtzman et al. 2000b; Fryer et al. 2003). In addition, the anatomical pattern of $\mathrm{A} \beta$ deposition differs in the absence of apoE (Holtzman et al. 2000a; Irizarry et al. 2000). The expression of human apoE isoforms in either PDAPP or Tg2576 Tg mice resulted in a marked delay in the deposition of $A \beta$ and formation of neuritic plaques, compared with APP Tg mice expressing no apoE or mouse apoE (Fagan et al. 2002; Fryer et al. 2005b). Importantly, expression of human apoE isoforms in APP Tg mice results in an isoform-specific effect on the amount of $A \beta$ accumulation as well as true amyloid deposits (E4 > E3 > E2) (Holtzman et al. 2000a; Fagan et al. 2002; Fryer et al. 2005b). In addition to the isoform-specific effects of human apoE on parenchymal $A \beta$ pathology, crossing human apoE knockin mice to Tg2576 mice resulted in a relative shift of $A \beta$ deposition from the brain parenchyma to arterioles in the form of CAA in apoE4 expressing mice relative to apoE3 or mouse apoE (Fryer et al. 2005b). A similar effect of apoE4 predisposing to CAA is seen in humans. These data strongly suggest that understanding the in vivo mechanisms underlying the apoE isoform-mediated difference in $A \beta$ accumulation is critical for relating these findings to the pathogenesis of $\mathrm{AD}$.

The underlying mechanism underlying how apoE influences $A \beta$ aggregation and accumulation in the brain is on its way to being elucidated. In vitro and in vivo studies suggest that apoE may influence $A \beta$ seeding and fibrillogenesis, as well as soluble $A \beta$ clearance. Lipid-free and lipidated (physiological) forms of apoE can interact with $\mathrm{A} \beta$ in vitro (Strittmatter et al. 1993b; LaDu et al. 1994; Sanan et al. 1994; Aleshkov et al. 1997; Yang et al. 1997; Tokuda et al. 2000). Most studies show that the efficiency of complex formation between lipidated 
D.M. Holtzman et al.

apoE and $\mathrm{A} \beta$ follows the order of apoE2 $>$ apoE3 $>>$ apoE4. The effect of apoE isoforms on $A \beta$ aggregation has also been investigated extensively in vitro. Some studies show apoE causing greater fibrillization $(\mathrm{E} 4>\mathrm{E} 3>\mathrm{E} 2)$ (Ma et al. 1994; Wisniewski et al. 1994; Castano et al. 1995), whereas others show that apoE inhibits fibrillization (Evans et al. 1994; Wood et al. 1996). Conflicting results between in vitro studies may be owing to the differences in apoE and $A \beta$ preparations or other factors. Altering the lipidation state of apoE in the brain is associated with strong effects on $\mathrm{A} \beta$ fibrillization in vivo. ATP-binding cassette A1 (ABCA1) normally lipidates apoE in the brain. When APP Tg mice are crossed onto an $A b c a 1^{-/-}$background, this decreases apoE lipidation and increases amyloid deposition (Hirsch-Reinshagen et al. 2005; Koldamova et al. 2005a; Wahrle et al. 2005), whereas increasing ABCA1 increases apoE lipidation and decreases amyloid deposition (Wahrle et al. 2008).

In addition to the effects of apoE on fibrillogenesis, there is evidence that apoE alters both the transport and clearance of soluble $A \beta$ in the brain (Fig. 1). A recent study shows that apoE isoforms do not differentially influence $A \beta$ production in vivo; however, apoE isoforms differentially affect $A \beta$ clearance before $A \beta$ deposition with $\mathrm{E} 4$ resulting in clearance that is slower than E3 and E2 (Castellano et al. 2011). These results suggest the difference in $A \beta$ accumulation between apoE isoforms is likely because of isoform-specific differences in $A \beta$ clearance. ApoE seems to play an important role in the clearance of $A \beta$ through several possible mechanisms. ApoE-containing lipoprotein particles may sequester $A \beta$ and modulate the cellular uptake of an apoE- $A \beta$ complex by receptor-mediated endocytosis. Alternatively, apoE may modulate $A \beta$ removal from the brain to the systemic circulation by transport across the blood-brain barrier. Data from in vitro studies support the idea that apoE facilitates the binding and internalization of soluble $A \beta$ by cells or its clearance via enzymes such as neprilysn (Beffert et al. 1998; Yang et al. 1999; Cole and Ard 2000; Koistinaho et al. 2004; Jiang et al. 2008). Although in vitro studies suggest that apoE enhances cellular $A \beta$ uptake and degradation (Kim et al. 2009a), there is in vivo evidence that apoE retards $A \beta$ clearance from the brain (DeMattos et al. 2004; Bell et al. 2007; Deane et al. 2008), possibly via an effect at the blood-brain barrier (BBB) (Fig. 1) (Zlokovic 2008). More work is clearly needed to determine the exact role that apoE has in modifying brain $\mathrm{A} \beta$ clearance, the role of the $\mathrm{BBB}$ in the process, and whether isoform-specific effects exist.

Several key questions remain to be further addressed regarding the effect of apoE on $A \beta$. Whether it is better to increase or decrease human apoE levels (regardless of isoform) to reduce $A \beta$ levels is still unanswered. Analyzing whether, and to what extent, altering human apoE level affects $A \beta$ pathology will help determine whether targeting apoE levels may be a viable therapeutic option for influencing $A \beta$ levels and toxicity, and ultimately treating $\mathrm{AD}$.

\section{ApoE RECEPTORS AND SYNAPTIC PLASTICITY}

The strong association of ApoE4 with late-onset $\mathrm{AD}$ raised the possibility that ApoE is mediating its powerful effect on the average age of disease onset at least in part through the receptors to which it binds. These ApoE receptors include the core, as well as potentially several more distantly related members of the LDLR gene family (Fig. 1). LRP1 has been repeatedly, albeit weakly, associated with $\mathrm{AD}$ risk (Beffert et al. 1999; Vazquez-Higuera et al. 2009), and a coding polymorphism in the distantly related Wnt coreceptor LRP6 has also been implicated (De Ferrari et al. 2007). None of the other family members have so far been convincingly associated with $\mathrm{AD}$ by human genetic data. The absence of genetic association, however, does not preclude important roles for these multifunctional receptors in the molecular mechanisms that underlie the disease process. The very nature of their essential functions during the development of the embryo in general (Herz et al. 1992; Johnson et al. 2005; Dietrich et al. 2010; Karner et al. 2010), and the brain, in particular (Willnow et al. 1996; Trommsdorff 
et al. 1999; May et al. 2004; Boycott et al. 2005; Boycott et al. 2009), may occlude their participation in $\mathrm{AD}$ pathogenesis, which would manifest itself much later in life.

Mechanisms by which ApoE receptors may contribute to $\mathrm{AD}$ development and progression may include roles in the control of inflammation (Lillis et al. 2008; Zurhove et al. 2008), cholesterol metabolism (reviewed in Herz et al. 2009), neurogenesis (Gajera et al. 2010), or the generation and trafficking of APP and $\mathrm{A} \beta$ (reviewed in the third section). Other potential mechanisms by which ApoE receptors may promote neuronal survival (Beffert et al. $2006 \mathrm{~b}$ ) during aging involve signaling pathways that control microtubule and actin dynamics (Beffert et al. 2002; Assadi et al. 2003; Brich et al. 2003; Ohkubo et al. 2003; Chai et al. 2009; Forster et al. 2010; Rust et al. 2010), dendritogenesis (Niu et al. 2004), spine formation (Niu et al. 2008), glutamate receptor function and synaptic plasticity (Zhuo et al. 2000; Weeber et al. 2002; Beffert et al. 2005; Chen et al. 2005; D'Arcangelo 2005; Sinagra et al. 2005; Groc et al. 2007; Durakoglugil et al. 2009; Korwek et al. 2009; Chen et al. 2010), as well as learning and memory (reviewed in Herz and Beffert 2000; Herz and Chen 2006; Bu 2009; Herz 2009). In this section we will mainly focus on the role of the ApoE receptors Apoer2 and Vldlr and their ligand Reelin in these processes.

\section{Molecular Basis of Signal Transduction by Neuronal ApoE Receptors}

ApoE receptors contain only short cytoplasmic tails, which lack functional enzymatic domains through which many cell-surface receptors transmit extracellular signals into the cell. However, they harbor a variety of short conserved sequence stretches, such as the tetra-amino acid NPxY motif, which serve as docking sites for a wide array of cytoplasmic adaptor and scaffolding proteins (Trommsdorff et al. 1998; Gotthardt et al. 2000; Beffert et al. 2005; Hoe et al. 2006a; Hoe et al. 2006b). The receptors can also interact as coreceptors through their extracellular domains with other types of signaling
Apolipoprotein E and Apolipoprotein E Receptors

proteins and modules, and thereby modulate their intrinsic activity (Boucher et al. 2002; Loukinova et al. 2002; Huang et al. 2003; Lillis et al. 2008; Zurhove et al. 2008), including that of the $N$-methyl-D-aspartate (NMDA) receptor (May et al. 2004; Beffert et al. 2005; Hoe et al. 2006b).

Apoer2 and Vldlr are a notable exception, inasmuch as they do not need to associate with another protein with intrinsic signal transduction activity to elicit an intracellular signal. Both receptors bind the large homo-oligomeric signaling protein Reelin with high affinity (D’Arcangelo et al. 1999; Hiesberger et al. 1999), resulting in their clustering at the plasma membrane (Strasser et al. 2004). The simultaneous interaction of the adapter protein Disabled 1 (Dab1) with NPxY motifs in their intracellular domains (ICDs) (Trommsdorff et al. 1998; Stolt et al. 2005) results in the progressive recruitment and transphosphorylation of Src family tyrosine kinases (SFKs) (Howell et al. 1997; Arnaud et al. 2003; Bock and Herz 2003). This in turn initiates a kinase casade inside the neuron, starting with the activation of phosphoinositide-3-kinase (PI3K), which subsequently activates protein kinase B (also known as Akt), and ending with the inhibition of glycogen synthase $3 \beta$ (GSK3 $\beta$ ) (Beffert et al. 2002), one of the primary kinases that phosphorylate the microtubule stabilizing protein tau on the same sites that are typically abnormally phosphorylated in the neurofibrillary tangles in the AD-afflicted brain.

Reelin signaling is essential for normal brain development by regulating a pathway that controls the migration and positioning of the neuronal cell bodies in their appropriate cortical layers of the neocortex and the cerebellum (Tissir and Goffinet 2003), as well as neuronal connectivity (Del Rio et al. 1997). Activation of SFKs is the "master switch" that is required for the initiation of all subsequent downstream signaling events, which are not limited to the control of GSK3 $\beta$ activity but also involve the regulation of Lis1-dependent nuclear translocation (Shu et al. 2004), n-cofilin-mediated actin reorganization (Chai et al. 2009; Frotscher 2010), and tyrosine phosphorylation of NMDA 
D.M. Holtzman et al.

receptor subunits (Beffert et al. 2005; Chen et al. 2005).

\section{Regulation of Tau Phosphorylation}

Genetic disruption of any component of this Reelin-Apoer2/Vldlr-Dab1 signaling pathway in the mouse, i.e., loss-of-function mutations in the ligand, the receptors, or the adaptor protein, results in reduced phosphorylation of GSK3 $\beta$ on an inhibitory serine residue, which leads to disinhibition of the enzyme and hyperphosphorylation of tau (Hiesberger et al. 1999; Beffert et al. 2002; Brich et al. 2003; Ohkubo et al. 2003). High levels of tau phosphorylation disrupt neuronal vesicle transport by compromising microtubule stability (Mudher et al. 2004), and consequently lead to variable degrees of neuronal dysfunction and premature death of signaling defective mutant mice (Sheldon et al. 1997; Trommsdorff et al. 1999; Brich et al. 2003). Intriguingly, genetic deficiency of tau prevents APP /A $\beta$-induced cognitive defects as well as excitotoxicity in mice (Roberson et al. 2007), indicating that the presence of abnormally phosphorylated tau, rather than its functional loss, is the likely reason for the severe motor defects that cause the premature death in the Reelin pathway mutants. This is further supported by a series of recent studies that showed a broad effect of mislocalized, phosphorylated tau on the spinodendritic targeting of Fyn (Ittner et al. 2010) and of the scaffolding protein JIP1 (Ittner et al. 2010), as well as on the disruption of glutamate receptor trafficking and recycling (Hoover et al. 2010). Intriguingly, the tau-induced synaptic defects are prevented or reversed by reducing the tau levels (Roberson et al. 2011; Sydow et al. 2011).

Loss of LRP1 also results in increased GSK3 $\beta$ activity, at least in fibroblasts and adipocytes, as a result of a loss of autocrine Wnt5a expression (Terrand et al. 2009). Conditional LRP1 knockout mice, lacking LRP1 expression exclusively in postmitotic neurons, also display severe locomotor abnormalities (May et al. 2004), raising the possibility that these dysfunctions could also be caused in part by defective regulation of tau phosphorylation, although this has not been explored at the time of this writing.

Tau hyperphosphorylation in Reelin signaling defective animals on a mixed strain background is highly variable (Hiesberger et al. 1999) and strongly dependent on the background strains. This observation was exploited in an unbiased approach to map genetic modifiers of ApoE receptor/Dab1-dependent tau phosphorylation in the mouse (Brich et al. 2003). Surprisingly, the strongest modifier mapped to a narrow genomic region centered around APP on mouse chromosome 16, in addition to a suggestive quantitative trait in the vicinity of Presenilin 1 on chromosome 12. Together these findings add further support to a model in which ApoE receptors functionally interact with APP, $A \beta$, and tau to control the molecular mechanisms that underlie the pathogenesis of AD.

\section{Regulation of Dendritic Spines, Glutamatergic Neurotransmission, and Synaptic Plasticity}

Numerous independent studies and observations point toward a role for Reelin and ApoE receptors in the formation of neuronal connections (Del Rio et al. 1997; Borrell et al. 2007) and the generation of dendritic complexity (Trommsdorff et al. 1999; Costa et al. 2001; Niu et al. 2004; Matsuki et al. 2008; Hoe et al. 2009). The latter may, however, not be entirely dependent on Apoer2 and Vldlr (Chameau et al. 2009) and may also involve interactions with APP (Hoe et al. 2009). Reelin signaling also regulates dendritic spine morphology (Costa et al. 2001; Niu et al. 2008; Pujadas et al. 2010), which likely involves regulation of actin dynamics and the participation of n-cofilin (Chai et al. 2009; Rust et al. 2010). It activates LIM kinase (LIMK), which inhibits the actin-depolymerizing activity of $\mathrm{n}$-cofilin. The dynamic remodeling of synaptic connections requires constant reorganization of actin filaments (Dillon and Goda 2005). Consequently, postnatal disruption of $\mathrm{n}$-cofilin in mice leads to increased synapse density and enlargement of axospinous synapses (Rust et al. 
2010) with defects in long-term potentiation (LTP) and long-term depression (LTD). Although synaptic AMPA receptor mobility is not affected, diffusion of extrasynaptic AMPA receptors is reduced owing to F-actin stabilization, preventing efficient egress of AMPA receptors from the synaptic into the extrasynaptic domain, and thus LTD, in the n-cofilin mutants. Similarly, Reelin has been shown to regulate surface mobility and synaptic residency of NMDA receptor NR2B subunits (Groc et al. 2007). It is thus required for NMDA receptor maturation (Sinagra et al. 2005) and for the maintenance of normal NR2A/B ratios (Campo et al. 2009).

These findings explain the profound effect of Reelin on glutamatergic neurotransmission and synaptic plasticity ex corpore (Weeber et al. 2002; Beffert et al. 2005; Beffert et al. 2006b; Qiu et al. 2006; Campo et al. 2009) and in vivo (Pujadas et al. 2010) (E Weeber, pers. comm.). Reelin potently increases LTP, which requires the presence of both receptors, Apoer2 and Vldlr (Weeber et al. 2002). This increase of synaptic plasticity is mediated by the effect Reelin has on NMDA and AMPA receptor trafficking and conductance, which determine the synaptic acitivity of these glutamate receptors (Qiu et al. 2006). It further requires the presence of a 59 amino acid insert encoded by an alternatively spliced exon in the cytoplasmic domain of Apoer2 (Beffert et al. 2005). Only when the insert is present can Apoer 2 functionally couple with NMDA receptors and induce tyrosine phosphorylation of NR2 subunits in response to Reelin. Increased tyrosine phosphorylation of the NMDA receptor increases ion gating and reduces its endocytosis, thereby increasing NMDA receptor activity overall (Salter and Kalia 2004; Snyder et al. 2005). Intriguingly, differential splicing of this exon is regulated in a circadian, activitydriven manner (Beffert et al. 2005), suggesting that periodic variation of NMDA receptor activity by Reelin is physiologically significant for synapse function, learning, and memory (Beffert et al. 2002; Weeber et al. 2002; Beffert et al. 2005; D'Arcangelo 2005; Beffert et al. 2006b; Pujadas et al. 2010).
Apolipoprotein E and Apolipoprotein E Receptors

ApoE Receptors as Antagonists of $A \beta$-Induced Synaptic Suppression

$\mathrm{A} \beta_{1-42}$ oligomers are strong inducers of synaptic suppression, and several mechanisms have been proposed to explain this effect (Lambert et al. 1998; Walsh et al. 2002; Lacor et al. 2004; Snyder et al. 2005; Lesne et al. 2006; Townsend et al. 2006; Haass and Selkoe 2007; Shankar et al. 2007; Berman et al. 2008; Puzzo et al. 2008; Shankar et al. 2008; Nygaard and Strittmatter 2009; Gimbel et al. 2010; Palop and Mucke 2010; Renner et al. 2010; Ronicke et al. 2010) (see Mucke and Selkoe 2011). Synaptic suppression by the oligomers correlates with reduced NMDA receptor activity (Snyder et al. 2005; Shankar et al. 2007), which is caused by NMDA receptor dephosphorylation and accelerated endocytosis (Snyder et al. 2005). Snyder, Greengard, and colleagues (Snyder et al. 2005) proposed that this is mediated by the $A \beta$-mediated activation of phosphatases (STEP and calcineurin). The concomitant reduction of NMDA receptor activity induces dendritic spine loss and, intriguingly, this requires calcineurin, as well as the active, i.e., Ser3-unphosphorylated form of n-cofilin (Shankar et al. 2007). A dominant negative form of $\mathrm{n}$-cofilin, in which Ser3 is replaced with a phosphomimetic amino acid (Ser3Asp), prevents oligomer-induced spine loss (Shankar et al. 2007).

Reelin induces the phosphorylation of ncofilin at the inhibitory Ser3 residue, thereby promoting spine stability (Chai et al. 2009; Frotscher 2010). Moreover, Reelin signaling activates SFKs (Chen et al. 2005), which would directly oppose the activity of the phosphatases on the NMDA receptor (Snyder et al. 2005). This hypothesis was tested by measuring the effect of different $A \beta$ preparations, including $\mathrm{A} \beta$-containing extracts from human $\mathrm{AD}$ brain, on hippocampal synaptic plasticity, NMDA receptor tyrosine phosphorylation, and activity in response to Reelin (Durakoglugil et al. 2009). At low to intermediate, but not at unphysiologically high (>400 nM) A $\beta$ concentrations, activation of Reelin signaling can completely prevent the synaptic suppression induced by the oligomers, suggesting that Reelin 
D.M. Holtzman et al.

is a physiological mediator of neuroprotection. Importantly, ApoE4 strongly interferes with these synapse-enhancing functions of Reelin by sequestering ApoE receptors in intracellular compartments (Chen et al. 2010) (Fig. 3), thus providing a novel mechanism by which accelerated spine loss, increased tau phosphorylation (Kocherhans et al. 2010), loss of network homeostasis (Palop et al. 2007; Palop and Mucke 2010), and earlier disease onset through loss of neuroprotective compensatory bandwidth (Korwek et al. 2009) can be readily explained. This mechanism is also consistent with the finding that ApoE4 reduces spine density and dendritic complexity in cortical neurons in vivo (Dumanis et al. 2009). Moreover, Reelin expression levels are reduced in the brains of $\mathrm{AD}$ patients and in the entorhinal cortex of APP overexpressing mice (Chin et al. 2007), suggesting that $A \beta$ can reduce Reelin expression in a subset of entorhinal pyramidal neurons, thereby adding further support to a role of diminished Reelin signaling in $\mathrm{AD}$ progression (Herz and Chen 2006).

\section{ApoE Receptors Protect against Neurodegeneration}

Recent evidence shows that ApoE receptors, specifically Apoer 2 and LRP1, directly protect against the loss of neurons and dendrites in vivo (Beffert et al. 2006b). Apoer2 was found to protect against the loss of corticospinal neurons during the normal aging process (Beffert et al. 2006b). This protection requires the presence of the alternatively spliced cytoplasmic

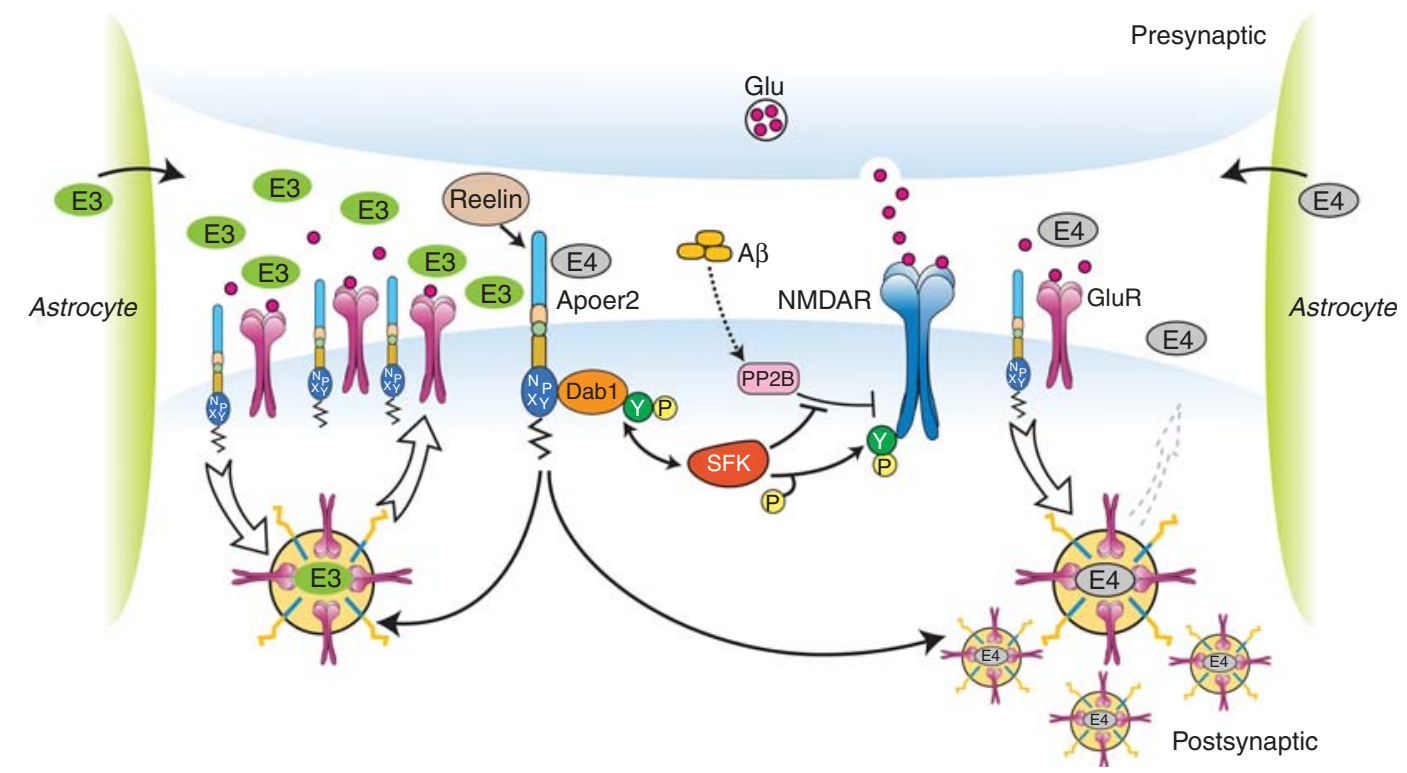

Figure 3. ApoE isoforms differentially impair ApoE receptor and glutamate receptor recycling at the synapse. Apoer2 induces $N$-methyl-D-aspartate receptor (NMDAR) tyrosine phosphorylation by activating Src family tyrosine kinases (SFKs) in response to Reelin in the postsynaptic neuron. Astrocyte-derived ApoE3 (green ovals) or ApoE4 (gray ovals) bind to Apoer2 and are constitutively but slowly internalized. Apoer2 undergoes accelerated endocytosis in response to Reelin signaling. ApoE4 sequesters Apoer2 in intracellular compartments along with glutamate receptors (NMDAR and GluR), thereby reducing the ability of the postsynaptic neuron to recycle these proteins with normal kinetics, whereas ApoE2 or ApoE3 efficiently recycle back to the cell surface and thus deplete surface Apoer2 and glutamate receptor levels to a lesser extent (illustrated on the left for ApoE3). A $\beta$ oligomers interfere with NMDAR tyrosine phosphorylation by activating tyrosine phosphatases (Snyder et al. 2005). (Modified from Chen et al. 2010; reprinted, with permission, from the National Academy of Sciences (C) 2010.) 
insert, which functionally couples Apoer2 to NMDA receptors, presumably through a PSD95-mediated interaction (Beffert et al. 2005; Hoe et al. 2006b), but also serves to recruit a c-jun amino-terminal kinase (JNK) signaling complex to the cytoplasmic tail of Apoer2 (Gotthardt et al. 2000; Stockinger et al. 2000). Intriguingly, JNK3 knockout mice and Apoer2 mutants lacking the alternatively spliced insert are resistant to lesion-induced neuronal death, suggesting that JNK recruitment to the Apoer2 cytoplasmic domain can promote both, neuronal loss or survival, depending on context (Beffert et al. 2006b).

Apoer2 also protects against neurodegeneration through another, mechanistically distinct mechanism, which involves its role in the uptake of essential selenoproteins into the brain (Burk et al. 2007). Loss of Apoer2 sensitizes the animals to low dietary selenium levels resulting in death from rapid and severe neurodegeneration. Selenoprotein 1 (Sepp1)-deficient animals show a pronounced LTP defect owing to selenium deficiency in the CNS when fed a selenium-reduced diet (Peters et al. 2006). However, the synaptic defects of Apoer2 knockin mutants (Beffert et al. 2005; Beffert et al. 2006a; Beffert et al. 2006b) are not caused by selenium depletion, but by the loss of NMDA and AMPA receptor regulation (Masiulis et al. 2009). LRP2 also mediates transport of this essential micronutrient (Chiu-Ugalde et al. 2010).

Neuroprotection by Apoer2 is further likely to involve its potent ability to mediate phosphorylation of cyclic AMP response element binding protein (CREB), a neuroprotective transcription factor that is also involved in longterm memory formation. $\mathrm{Ca}^{2+}$ influx through synaptic NMDA receptors stimulates CREB phosphorylation and promotes neuronal survival, whereas excitotoxic stimulation of extrasynaptic NMDA receptors shuts off CREB phosphorylation and promotes neuronal death (Hardingham et al. 2002). Reelin signaling strongly promotes CREB phosphorylation in cultured primary cortical neurons and this requires NMDA receptor activity (Chen et al. 2005). However, this is almost completely prevented by ApoE4 (Chen et al. 2010), suggesting
Apolipoprotein E and Apolipoprotein E Receptors

another potential mechanism by which this apolipoprotein may contribute to the premature onset of neurodegeneration in ApoE4 carriers.

\section{LRP1: EFFECTS ON APP, A $\beta$, AND ApoE METABOLISM}

\section{Regulation of APP Trafficking and Processing by LRP1 and Other ApoE Receptors}

The $\beta$-secretase BACE1 is abundantly present and active in acidic endosomes (Cole and Vassar 2007). Consequently, increased APP endocytosis and distribution in endosomes lead to increased amyloidogenic processing and $A \beta$ production. Conversely, if APP is retained at the cell surface, it has a greater availability for the cell-surface-localized $\alpha$-secretase and is cleaved to $\operatorname{sAPP} \alpha$ and a minimally toxic peptide p3 (see Haass et al. 2011 for details). Therefore, APP-interacting proteins or cellular conditions that alter APP trafficking and/or distribution are expected to impact APP processing to $A \beta$. Indeed, several apoE receptors interact with APP and modulate its trafficking and processing. LRP1 interacts with APP extracellularly by binding to the Kunitz-type protease inhibitor (KPI) domain that is present in the longer forms of APP (APP751 and APP770) (Kounnas et al. 1995). Further studies showed that LRP1 also interacts with the neuronal isoform of APP lacking the KPI domain (APP695). Two different phosphotyrosinebinding (PTB) domains within the adaptor protein FE65 bind to the NPxY motifs within APP and LRP1, thus bridging an interaction between these two membrane proteins intracellularly (Trommsdorff et al. 1998; Kinoshita et al. 2001; Pietrzik et al. 2004). Because of the rapid endocytosis rate of LRP1 compared with that of APP (Cam et al. 2005), the consequence of APP and LRP1 interaction is accelerated APP endocytic trafficking and processing to $A \beta$ (Ulery et al. 2000; Zerbinatti et al. 2004; Cam et al. 2005; Zerbinatti et al. 2006). The in vivo role of LRP1 in APP trafficking and processing requires further investigation. 
D.M. Holtzman et al.

Several other apoE receptors also interact with APP and regulate its trafficking and processing to $A \beta$. LRP1B, which shares high sequence homology with LRP1 but has a significantly slower rate of endocytosis retains APP at the cell surface and reduces its processing to $A \beta$ (Cam et al. 2004). Apoer2 either decreases or increases $A \beta$ production depending on the experimental conditions. In the presence of Fspondin, a common ligand that bridges APP and Apoer2 extracellular interaction, the slow endocytosis rate of Apoer2 inhibits APP endocytic trafficking and reduces $A \beta$ production (Hoe et al. 2005). However, in the absence of common ligands, Apoer 2 increases the distribution of APP into lipid rafts and APP processing to $A \beta$ (Fuentealba et al. 2007). A third apoE receptor that modulates APP trafficking and processing to $A \beta$ is sorLA/LR11 whose expression is significantly reduced in $\mathrm{AD}$ brains (Scherzer et al. 2004). Cell biological studies show that sorLA in neurons shifts APP distribution to the Golgi compartment and decreases its processing to A $\beta$ (Andersen et al. 2005). Importantly, a deletion of the Sorla gene in mice increases concentration of $A \beta$ in the brain (Andersen et al. 2005). Supporting a role for sorLA in AD pathogenesis, a genetic study showed that inherited variants in the SORL1 gene (which encodes sorLA) are associated with LOAD (Rogaeva et al. 2007). Collectively, these studies show that apoE receptors are intimately associated with APP in neurons and regulate APP trafficking and processing.

\section{LRP1 and LDLR in Cellular and Brain A $\beta$ Metabolism}

Impaired $A \beta$ clearance is likely a major pathogenic event for LOAD. There are two major pathways by which $A \beta$ is cleared from the brain: (1) receptor-mediated clearance by cells in brain parenchyma (microglia, astrocytes, neurons), along the interstitial fluid (ISF) drainage pathway or through the BBB and (2) through endopeptidase-mediated proteolytic degradation (see Saido and Leissring 2011 for details on proteolytic degradation of $A \beta$ ). Receptor-mediated clearance of $A \beta$ in the brain is at least partially mediated by the apoE receptors LRP1, LDLR, and VLDLR, which are widely expressed in neurons, astrocytes, and microglia of brain parenchyma, as well as in endothelial cells, astrocytes, and smooth muscle cells at the BBB and cerebral arteries.

The best-characterized $A \beta$ clearance receptor in the brain is LRP1, which along with several of its ligands are present in amyloid plaques (Rebeck et al. 1995). The important function of LRP1 in brain A $\beta$ clearance was shown in amyloid mouse model with decreased LRP1 expression owing to a deletion of their chaperone RAP (Van Uden et al. 2002). Recombinant RAP and LRP1 antibody also reduce $A \beta$ efflux from mouse brain (Shibata et al. 2000). In humans, a decreased LRP1 expression in the brain capillaries in $\mathrm{AD}$ brains may contribute to impaired A $\beta$ clearance (Deane et al. 2004), whereas circulating soluble LRP1 (sLRP) might provide peripheral "sink" activity for $A \beta$ clearance through the BBB (Sagare et al. 2007).

LRP1 binds A $\beta$ directly (Deane et al. 2004) or indirectly via its ligands, which include $\alpha 2$ macroglobulin (Narita et al. 1997), RAP (Kanekiyo and $\mathrm{Bu} 2009$ ), and apoE (Bu 2009; Kim et al. 2009a). ApoE is the best-characterized $\mathrm{A} \beta$ chaperone. Because apoE immunoreactivity is commonly found in amyloid plaques (Namba et al. 1991; Wisniewski and Frangione 1992), it is likely that apoE interacts with $\mathrm{A} \beta$ directly in the human brain. The region of apoE that is responsible for $A \beta$ binding is in the carboxy-terminal domain overlapping with the lipid-binding region (Strittmatter et al. 1993b; Tamamizu-Kato et al. 2008), suggesting that the lipophilic $\mathrm{A} \beta$ peptide associates with apoE in a process that is analogous to lipid binding. Indeed, $A \beta$ binding to apoE compromises its lipid-binding function (Tamamizu-Kato et al. 2008). Furthermore, $A \beta$ peptides modulate the binding of apoE isoforms differently to apoE receptors (Beffert et al. 1998; Hone et al. 2005). These results show that $A \beta$ peptides can interfere with the normal function of apoE under in vitro conditions. It is unclear if in vivo this is the case. A fraction of apoE3/lipoprotein binds to $A \beta$ with higher affinity than apoE4/lipoprotein (LaDu et al. 1994). How- 
ever, whether $\mathrm{A} \beta$ binding to apoE/lipoprotein leads to enhanced or reduced $A \beta$ clearance, has not yet been clarifed (Kim et al. 2009a). If $A \beta$ is cleared more efficiently through apoE/ lipoprotein-independent pathway, one would expect that $A \beta$ binding to apoE/lipoprotein will impede its clearance. On the other hand, if apoE/lipoprotein/A $\beta$ complexes enter cells via apoE receptor (e.g., LRP1 and LDLR) pathways more efficiently than $A \beta$ alone, apoE/ lipoprotein likely promotes $A \beta$ clearance. The in vivo role of apoE/lipoprotein in $A \beta$ clearance is likely influenced by apoE lipidation state, receptor expression, and local $\mathrm{A} \beta$ concentration ( $\mathrm{Bu}$ 2009; Kim et al. 2009a). Interestingly, a recent study shows that $A \beta$ binding to apoE4 redirects its clearance from LRP1 to VLDLR, which internalizes $A \beta$-apoE4 complexes at the BBB more slowly than LRP1 (Deane et al. 2008). In contrast, $A \beta$-apoE 2 and $A \beta$-apoE 3 complexes are cleared at the $\mathrm{BBB}$ via both VLDLR and LRP1 at a substantially faster rate than $A \beta$-apoE4 complexes.

LDLR is another receptor that is implicated in brain $A \beta$ clearance, although the effects of LDLR loss-of-function on $A \beta$ clearance are still being worked out. One study showed that LDLR deficiency was associated with increased amyloid deposition in Tg2576 APP-transgenic mice (Cao et al. 2006). In contrast, another study using PDAPP-transgenic mice did not find a significant effect of $L d l r$ deletion on $A \beta$ level or deposition although there was a trend for increased $A \beta$ in the absence of LDLR (Fryer et al. 2005a). Using a gain-of-function approach, a more recent study showed that overexpression of the LDLR in the brain of transgenic mice enhanced $A \beta$ clearance and decreased $A \beta$ deposition (Kim et al. 2009b). It is not clear whether the effect of LDLR overexpression on $A \beta$ clearance is because of the reduced level of apoE in the LDLR transgenic mice, or a direct effect on $A \beta$, or both. Nonetheless, these findings indicate that increasing LDLR expression may represent a novel therapeutic strategy to treat $\mathrm{AD}$.

The receptor-mediated clearance is, in principle, an efficient way of reducing brain $A \beta$ because most $A \beta$ that is internalized by apoE
Apolipoprotein E and Apolipoprotein E Receptors

receptors is delivered to lysosomes for degradation (see Fig. 4) or transcytosed into the plasma via $\mathrm{BBB}$. However, it is possible that receptor-mediated clearance of $A \beta$ into neurons can lead to intraneuronal accumulation of $A \beta$ (Fig. 3), which under certain conditions may be toxic (Billings et al. 2005). A portion of $A \beta$ that is internalized by neurons, in particular oligomeric $A \beta 42$, accumulates in multivesicular bodies (MVBs)/late endosomes and lysosomes, and contributes to lysosomal dysfunction and neuronal toxicity. In contrast, receptormediated internalization of $A \beta$ by astrocytes (Koistinaho et al. 2004) and microglia (Mandrekar et al. 2009) is likely to represent a more functional pathway to clear and eventually degrade $A \beta$.

\section{Evidence that LRP1 and LDLR Are Key} Metabolic Receptors for ApoE/Lipoprotein in the Brain

Although several LDLR family members are expressed in the brain, accumulating evidence indicates that the LDLR and LRP1 are the two primary metabolic receptors for apoE/lipoprotein. Deletion of the Ldlr gene in mice increases apoE levels in brain parenchyma and CSF (Fryer et al. 2005a), suggesting impaired metabolism of apoE. In contrast, overexpression of the LDLR in the brain decreases apoE levels, reflecting an increased metabolism of apoE (Kim et al. 2009b). Similarly, conditional deletion of the Lrp1 gene in mouse forebrain neurons increases apoE levels (Liu et al. 2007) and overexpression of a functional LRP1 minireceptor in mouse brain decreases brain apoE levels (Zerbinatti et al. 2006). Although both LDLR and LRP1 play roles in brain apoE/lipoprotein metabolism, there are important differences between them. First, whereas LRP1 is highly expressed in neurons and to a lesser degree in glia, LDLR is more prominently expressed in glia than neurons (Rebeck et al. 1993; Rapp et al. 2006). Second, deletion of the $\operatorname{Lrp} 1$ gene in mouse forebrain neurons reduces brain cholesterol levels (Liu et al. 2007), whereas cholesterol levels in Ldlr knockout mice are unchanged (Fryer et al. 2005a). Third, apoE/lipoprotein 
D.M. Holtzman et al.

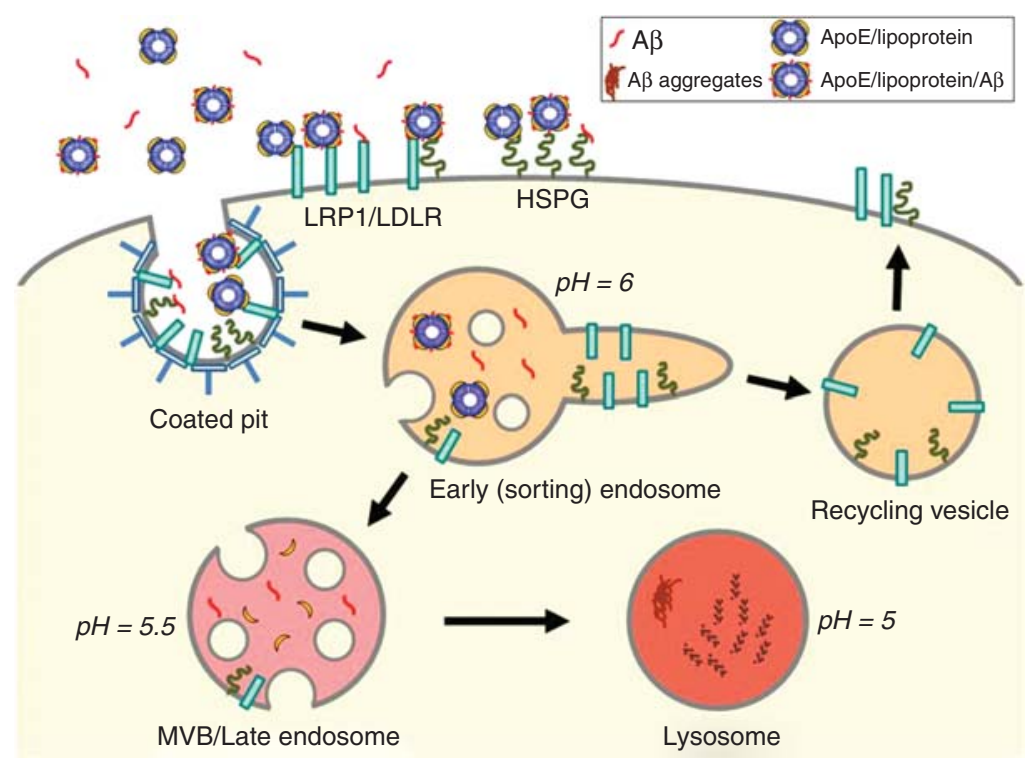

Figure 4. Schematic model of LRP1/LDLR-mediated cellular transport of apoE/lipoprotein and A $\beta$. Three cellsurface receptors, LRP1, LDLR, and HSPG, are capable of binding to apoE/lipoprotein, A $\beta$, and apoE/lipoprotein/A $\beta$ complexes. On clathrin-mediated endocytosis, ligands are mostly dissociated from the receptors within the early/sorting endosomes owing to lower $\mathrm{pH}$. Whereas receptors are typically recycled back to the cell surface, ligands are delivered to multivesicular bodies (MVBs)/late endosomes and eventually to lysosomes for degradation. Lipid components are transported out of the lysosomes for storage or reutilization. Depending on the concentrations and cellular conditions, some $A \beta$ molecules might aggregate within the lysosomes as intracellular $A \beta$, which could eventually serve to seed amyloid plaques (Hu et al. 2009).

particles secreted by astrocytes have higher affinity for LDLR than LRP1 (Fryer et al. 2005a), whereas recombinant apoE (Narita et al. 2002), apoE-enriched lipoprotein particles (Kowal et al. 1990), and CSF-isolated HDL particles (Fagan et al. 1996) bind more avidly to LRP1. The receptor-binding specificity of apoE is likely influenced by its conformation and lipidation state. It is possible that apoE/lipoprotein particles secreted by astrocytes recruit additional apoE molecules, perhaps bound to heparan sulfate proteoglycan (HSPG), before being transported to the CSF or binding to LRP1 at the neuronal cell surface.

There is some evidence that apoE isoforms may differ in their function in regard to cholesterol transport and efflux (Michikawa et al. 2000; Gong et al. 2002; Rapp et al. 2006), although not all studies show this (Hirsch-Reinshagen et al. 2004). Thus the roles of apoE isoforms in brain cholesterol metabolism require further investigation. The structural differences among apoE isoforms that determine their lipid- and receptor-binding specificities in the brain environment could account for their differences in modulating brain cholesterol metabolism. It is important to note that there are likely LRP1-mediated cholesterol transport mechanisms in the brain that are independent of apoE because LRP1 deficiency in the brain, but not apoE deficiency, leads to decreased brain cholesterol levels. Other LRP1 ligands such as lipoprotein lipase might also play a role. Alternatively, LRP1 may serve as a cholesterol sensor that influences cholesterol synthesis and/or intracellular transport.

In addition to cholesterol, apoE also mediates the transport of other brain lipids, some of which are not produced in astrocytes. For example, sulfatide, an oligodendrocyte-synthesized lipid that is crucial for neuronal spine and myelin sheath integrity, is actively transported 
by an apoE- and LRP1-dependent mechanism (Han 2007). It is possible that apoE/lipoprotein particles are modified by myelin-associated lipids before being transported into neurons. Interestingly, sulfatide is a potential biomarker for $\mathrm{AD}$ diagnosis as its levels are decreased in AD brains (Han 2007). Whether LRP1/LDLRmediated apoE/cholesterol transport is impaired in $\mathrm{AD}$ brains and how this in turn contributes to $\mathrm{AD}$ pathogenesis is currently not clear. However, because of the important role of apoE/cholesterol in injury repair, the cholesterol transport pathway should be considered when apoE/LRP1/LDLR pathways are explored as therapeutic targets for $\mathrm{AD}$.

\section{SUMMARY}

$A P O E$ genotype is the strongest genetic risk factor for $\mathrm{AD}$, and understanding the mechanism underlying this relationship has the potential to lead to new therapeutic approaches. A major reason that appears to underlie this relationship is the fact that apoE isoforms result in differential onset of $A \beta$ accumulation in the brain with the onset E4 earlier than E3, which is earlier than E2. There is direct in vivo evidence that differences in $A \beta$ clearance is one factor that accounts for this (Castellano et al. 2011), although effects of apoE on $A \beta$ aggregation independent of clearance may also be important. From a therapeutic standpoint, pathways that stimulate $A \beta$ clearance via apoE-dependent mechanisms are one possible approach to decrease $A \beta$ accumulation and its toxic effects. Targeting the liver $\mathrm{X}$ receptor (LXR) pathway (Koldamova et al. 2005b), apoE lipidation state via ABCA1, as well as LDLR, LRP1, and other apoE receptors are potential ways to stimulate apoE-dependent $A \beta$ clearance. In terms of apoE-dependent $A \beta$ aggregation, interrupting the apoE-A $\beta$ interaction may also have therapeutic potential (Sadowski et al. 2006). In addition to effects on the apoE/A $\beta$ pathway, apoE receptors such as Apoer2 and Vldlr play important roles in synaptic plasticity, tau phosphorylation, and neuroprotection. Determining ways to activate these receptors may be
Apolipoprotein E and Apolipoprotein E Receptors

another strategy to delay or halt the progressive neurodegenerative process that occurs in $\mathrm{AD}$.

\section{REFERENCES}

${ }^{*}$ Reference is also in this collection.

Aleshkov S, Abraham CR, Zannis VI. 1997. Interaction of nascent apoE2, apoE3, and apoE4 isoforms expressed in mammalian cells with amyloid peptide $\beta$ (1-40). Relevance to Alzheimer's disease. Biochemistry 36: 1057110580.

Andersen OM, Reiche J, Schmidt V, Gotthardt M, Spoelgen R, Behlke J, von Arnim CA, Breiderhoff T, Jansen P, Wu X, et al. 2005. Neuronal sorting protein-related receptor sorLA/LR11 regulates processing of the amyloid precursor protein. In Proc Natl Acad Sci 102: 13461-13466.

Anderson R, Barnes JC, Bliss TV, Cain DP, Cambon K, Davies HA, Errington ML, Fellows LA, Gray RA, Hoh T, et al. 1998. Behavioural, physiological and morphological analysis of a line of apolipoprotein E knockout mouse. Neuroscience 85: 93-110.

Arnaud L, Ballif BA, Forster E, Cooper JA. 2003. Fyn tyrosine kinase is a critical regulator of disabled-1 during brain development. Curr Biol 13: 9-17.

Assadi AH, Zhang G, Beffert U, McNeil RS, Renfro AL, Niu S, Quattrocchi CC, Antalffy BA, Sheldon M, Armstrong $\mathrm{DD}$, et al. 2003. Interaction of reelin signaling and Lis 1 in brain development. Nat Genet 35: 270-276.

Bales KR, Verina T, Dodel RC, Du Y, Altstiel L, Bender M, Hyslop P, Johnstone EM, Little SP, Cummins DJ, et al. 1997. Lack of apolipoprotein E dramatically reduces amyloid $\beta$-peptide deposition. Nat Genet 17: 263-264.

Bales KR, Verina T, Cummins DJ, Du Y, Dodel JC, Saura J, Fishman CE, DeLong CA, Piccardo P, Petegnief V, et al. 1999. Apolipoprotein E is essential for amyloid deposition in the APPV717F transgenic mouse model of Alzheimer's disease. Proc Natl Acad Sci 96: 1523315238.

Beffert U, Arguin C, Poirier J. 1999. The polymorphism in exon 3 of the low density lipoprotein receptor-related protein gene is weakly associated with Alzheimer's disease. Neurosci Lett 259: 29-32.

Beffert U, Aumont N, Dea D, Lussier-Cacan S, Davignon J, Poirier J. 1998. $\beta$-amyloid peptides increase the binding and internalization of apolipoprotein $\mathrm{E}$ to hippocampal neurons. J Neurochem 70: 1458-1466.

Beffert U, Morfini G, Bock HH, Reyna H, Brady ST, Herz J. 2002. Reelin-mediated signaling locally regulates protein kinase B/Akt and glycogen synthase kinase $3 \beta$. J Biol Chem 277: 49958-49964.

Beffert U, Weeber EJ, Durudas A, Qiu S, Masiulis I, Sweatt JD, Li WP, Adelmann G, Frotscher M, Hammer RE et al. 2005. Modulation of synaptic plasticity and memory by Reelin involves differential splicing of the lipoprotein receptor Apoer2. Neuron 47: 567-579.

Beffert U, Durudas A, Weeber EJ, Stolt PC, Giehl KM, Sweatt JD, Hammer RE, Herz J. 2006a. Functional dissection of Reelin signaling by site-directed disruption of Disabled-1 adaptor binding to apolipoprotein E receptor 2: Distinct 
D.M. Holtzman et al.

roles in development and synaptic plasticity. J Neurosci 26: 2041-2052.

Beffert U, Nematollah Farsian F, Masiulis I, Hammer RE, Yoon SO, Giehl KM, Herz J. 2006b. ApoE receptor 2 controls neuronal survival in the adult brain. Curr Biol 16: 2446-2452.

Bell RD, Sagare AP, Friedman AE, Bedi GS, Holtzman DM, Deane R, Zlokovic BV. 2007. Transport pathways for clearance of human Alzheimer's amyloid $\beta$-peptide and apolipoproteins $\mathrm{E}$ and $\mathrm{J}$ in the mouse central nervous system. J Cereb Blood Flow Metab 27: 909-918.

Benjamin R, Leake A, Ince PG, Perry RH, McKeith IG, Edwardson JA, Morris CM. 1995. Effects of apolipoprotein E genotype on cortical neuropathology in senile dementia of the Lewy body and Alzheimer's disease. Neurodegeneration 4: 443-448.

Berman DE, Dall'Armi C, Voronov SV, McIntire LB, Zhang H, Moore AZ, Staniszewski A, Arancio O, Kim TW, Di Paolo G. 2008. Oligomeric amyloid- $\beta$ peptide disrupts phosphatidylinositol-4,5-bisphosphate metabolism. Nat Neurosci 11: 547-554.

Bertram L, McQueen MB, Mullin K, Blacker D, Tanzi RE. 2007. Systematic meta-analyses of Alzheimer disease genetic association studies: The AlzGene database. Nat Genet 39: 17-23.

Billings LM, Oddo S, Green KN, McGaugh JL, Laferla FM 2005. Intraneuronal $A \beta$ causes the onset of early Alzheimer's disease-related cognitive deficits in transgenic mice. Neuron 45: 675-688.

Bock HH, Herz J. 2003. Reelin activates SRC family tyrosine kinases in neurons. Curr Biol 13: 18-26.

Borrell V, Pujadas L, Simo S, Dura D, Sole M, Cooper JA, Del Rio JA, Soriano E. 2007. Reelin and mDab1 regulate the development of hippocampal connections. Mol Cell Neurosci 36: 158-173.

Boucher P, Liu P, Gotthardt M, Hiesberger T, Anderson RG, Herz J. 2002. Platelet-derived growth factor mediates tyrosine phosphorylation of the cytoplasmic domain of the low density lipoprotein receptor-related protein in caveolae. J Biol Chem 277: 15507-15513.

Boycott KM, Flavelle S, Bureau A, Glass HC, Fujiwara TM, Wirrell E, Davey K, Chudley AE, Scott JN, McLeod DR, et al. 2005. Homozygous deletion of the very low density lipoprotein receptor gene causes autosomal recessive cerebellar hypoplasia with cerebral gyral simplification. Am J Human Genet 77: 477-483.

Boycott KM, Bonnemann C, Herz J, Neuert S, Beaulieu C, Scott JN, Venkatasubramanian A, Parboosingh JS. 2009 Mutations in VLDLR as a cause for autosomal recessive cerebellar ataxia with mental retardation (dysequilibrium syndrome). J Child Neurol 24: 1310-1315.

Brich J, Shie FS, Howell BW, Li R, Tus K, Wakeland EK, Jin LW, Mumby M, Churchill G, Herz J, et al. 2003. Genetic modulation of tau phosphorylation in the mouse. J Neurosci 23: $187-192$.

$\mathrm{Bu}$ G. 2009. Apolipoprotein $\mathrm{E}$ and its receptors in Alzheimer's disease: Pathways, pathogenesis and therapy. Nat Rev Neurosci 10: 333-344.

Burk RF, Hill KE, Olson GE, Weeber EJ, Motley AK, Winfrey VP, Austin LM. 2007. Deletion of apolipoprotein E receptor-2 in mice lowers brain selenium and causes severe neurological dysfunction and death when a lowselenium diet is fed. J Neurosci 27: 6207-6211.

Cam JA, Zerbinatti CV, Knisely JM, Hecimovic S, Li Y, Bu G. 2004. The low density lipoprotein receptor-related protein $1 \mathrm{~B}$ retains $\beta$-amyloid precursor protein at the cell surface and reduces amyloid- $\beta$ peptide production. J Biol Chem 279: 29639-29646.

Cam JA, Zerbinatti CV, Li Y, Bu G. 2005. Rapid endocytosis of the low density lipoprotein receptor-related protein modulates cell surface distribution and processing of the $\beta$-amyloid precursor protein. J Biol Chem 280: 15464-15470.

Campo CG, Sinagra M, Verrier D, Manzoni OJ, Chavis P. 2009. Reelin secreted by GABAergic neurons regulates glutamate receptor homeostasis. PLoS One 4: e5505. doi: 10.1371/journal.pone.0005505.

Cao D, Fukuchi K, Wan H, Kim H, Li L. 2006. Lack of LDL receptor aggravates learning deficits and amyloid deposits in Alzheimer transgenic mice. Neurobiol Aging 27: 1632-1643.

Castano EM, Prelli F, Wisniewski T, Golabek A, Kumar RA, Soto C, Frangione B. 1995. Fibrillogenesis in Alzheimer's disease of amyloid $\beta$ peptides and apolipoprotein E. Biochem J 306: 599-604.

Castellano JM, Kim J, Stewart FR, DeMattos RB, Patterson BW, Fagan AM, Morris JC, Mawuenyega KG, Paul SM, Bateman RJ, et al. 2011. Human apoE isoforms differentially regulate brain amyloid- $\beta$ peptide clearance. $S c i$ Transl Med 3: 89ra57.

Chai X, Forster E, Zhao S, Bock HH, Frotscher M. 2009. Reelin acts as a stop signal for radially migrating neurons by inducing phosphorylation of $\mathrm{n}$-cofilin at the leading edge. Commun Integr Biol 2: 375-377.

Chameau P, Inta D, Vitalis T, Monyer H, Wadman WJ, van Hooft JA. 2009. The N-terminal region of reelin regulates postnatal dendritic maturation of cortical pyramidal neurons. Proc Natl Acad Sci 106: 7227-7232.

Chen Y, Beffert U, Ertunc M, Tang TS, Kavalali ET, Bezprozvanny I, Herz J. 2005. Reelin modulates NMDA receptor activity in cortical neurons. J Neurosci 25: 8209-8216.

Chen Y, Durakoglugil MS, Xian X, Herz J. 2010. ApoE4 reduces glutamate receptor function and synaptic plasticity by selectively impairing ApoE receptor recycling. Proc Natl Acad Sci 107: 12011-12016.

Chin J, Massaro CM, Palop JJ, Thwin MT, Yu GQ, Bien-Ly N, Bender A, Mucke L. 2007. Reelin depletion in the entorhinal cortex of human amyloid precursor protein transgenic mice and humans with Alzheimer's disease. J Neurosci 27: 2727-2733.

Chiu-Ugalde J, Theilig F, Behrends T, Drebes J, Sieland C, Subbarayal P, Kohrle J, Hammes A, Schomburg L, Schweizer U. 2010. Mutation of megalin leads to urinary loss of selenoprotein $\mathrm{P}$ and selenium deficiency in serum, liver, kidneys and brain. Biochem J 431: 103-111.

Cirrito JR, Deane R, Fagan AM, Spinner ML, Parsadanian M, Finn MB, Jiang H, Prior JL, Sagare A, Bales KR, et al. 2005. P-glycoprotein deficiency at the blood-brain barrier increases amyloid- $\beta$ deposition in an Alzheimer disease mouse model. J Clin Invest 115: 3285-3290.

Cole GM, Ard MD. 2000. Influence of lipoproteins on microglial degradation of Alzheimer's amyloid $\beta$-protein. Microsc Res Tech 50: 316-324. 
Apolipoprotein E and Apolipoprotein E Receptors

Cole SL, Vassar R. 2007. The Alzheimer's disease $\beta$-secretase enzyme, BACE1. Mol Neurodegener 2: 22.

Corder EH, Saunders AM, Strittmatter WJ, Schmechel DE, Gaskell PC, Small GW, Roses AD, Haines JL, Pericak-Vance MA. 1993. Gene dose of apolipoprotein E type 4 allele and the risk of Alzheimer's disease in late onset families. Science 261: 921-923.

Corder EH, Saunders AM, Risch NJ, Strittmatter WJ, Schmechel DE, Gaskell PC Jr, Rimmler JB, Locke PA, Conneally PM, Schmader KE, et al. 1994. Protective effect of apolipoprotein E type 2 allele for late onset Alzheimer disease. Nat Genet 7: 180-184.

Costa E, Davis J, Grayson DR, Guidotti A, Pappas GD, Pesold C. 2001. Dendritic spine hypoplasticity and downregulation of reelin and GABAergic tone in schizophrenia vulnerability. Neurobiol Dis 8: 723-742.

D’Arcangelo G. 2005. Apoer2: A reelin receptor to remember. Neuron 47: 471-473.

D’Arcangelo G, Homayouni R, Keshvara L, Rice DS, Sheldon M, Curran T. 1999. Reelin is a ligand for lipoprotein receptors. Neuron 24: 471-479.

Deane R, Wu Z, Sagare A, Davis J, Du Yan S, Hamm K, Xu F, Parisi M, LaRue B, Hu HW, et al. 2004. LRP/amyloid $\beta$-peptide interaction mediates differential brain efflux of A $\beta$ isoforms. Neuron 43: 333-344.

Deane R, Sagare A, Hamm K, Parisi M, Lane S, Finn MB, Holtzman DM, Zlokovic BV. 2008. apoE isoform-specific disruption of amyloid $\beta$ peptide clearance from mouse brain. J Clin Invest 118: 4002-4013.

De Ferrari GV, Papassotiropoulos A, Biechele T, Wavrant De-Vrieze F, Avila ME, Major MB, Myers A, Saez K, Henriquez JP, Zhao A, et al. 2007. Common genetic variation within the low-density lipoprotein receptor-related protein 6 and late-onset Alzheimer's disease. Proc Natl Acad Sci 104: 9434-9439.

Del Rio JA, Heimrich B, Borrell V, Forster E, Drakew A, Alcantara S, Nakajima K, Miyata T, Ogawa M, Mikoshiba $\mathrm{K}$, et al. 1997. A role for Cajal-Retzius cells and reelin in the development of hippocampal connections. Nature 385: 70-74.

DeMattos RB, Brendza RP, Heuser JE, Kierson M, Cirrito JR, Fryer JD, Sullivan PM, Fagan AM, Han X, Holtzman DM. 2001. Purification and characterization of astrocytesecreted apolipoprotein $\mathrm{E}$ and J-containing lipoproteins from wild-type and human apoE transgenic mice. Neurochem Int 39: 415-425.

DeMattos RB, O'dell MA, Parsadanian M, Taylor JW, Harmony JAK, Bales KR, Paul SM, Aronow BJ, Holtzman DM. 2002. Clusterin promotes amyloid plaque formation and is critical for neuritic toxicity in a mouse model of Alzheimer's disease. Proc Natl Acad Sci 10: 10843-10848.

DeMattos RB, Cirrito JR, Parsadanian M, May PC, O’Dell MA, Taylor JM, Harmony JAK, Aronow BJ, Bales KR, Paul SM, et al. 2004. ApoE and clusterin cooperatively suppress $\mathrm{Ab}$ levels and deposition: Evidence that apoE regulates extracellular $\mathrm{Ab}$ metabolism in vivo. Neuron 41: 193-202.

Dieckmann M, Dietrich MF, Herz J. 2010. Lipoprotein receptors-An evolutionarily ancient multifunctional receptor family. Biol Chem 391: 1341-1363.
Dietrich MF, van der Weyden L, Prosser HM, Bradley A, Herz J, Adams DJ. 2010. Ectodomains of the LDL receptor-related proteins LRP1b and LRP4 have anchorage independent functions in vivo. PLoS One 5: e9960. doi: 10.1371/journal.pone.0009960.

Dillon C, Goda Y. 2005. The actin cytoskeleton: Integrating form and function at the synapse. Annu Rev Neurosci 28: 25-55.

Dumanis SB, Tesoriero JA, Babus LW, Nguyen MT, Trotter JH, Ladu MJ, Weeber EJ, Turner RS, Xu B, Rebeck GW, et al. 2009. ApoE4 decreases spine density and dendritic complexity in cortical neurons in vivo. J Neurosci 29: 15317-15322.

Durakoglugil MS, Chen Y, White CL, Kavalali ET, Herz J. 2009. Reelin signaling antagonizes $\beta$-amyloid at the synapse. Proc Natl Acad Sci 106: 15938-15943.

Evans KC, Berger EP, Cho C-G, Weisgraber KH, Lansbury PT. 1994. Apolipoprotein E is a kinetic but not a thermodynamic inhibitor of amyloid formation: Implications for the pathogenesis and treatment of Alzheimer's disease. Proc Natl Acad Sci 92: 763-767.

Fagan AM, Bu G, Sun Y, Daugherty A, Holtzman DM. 1996. Apolipoprotein E-containing high density lipoprotein promotes neurite outgrowth and is a ligand for the low density lipoprotein receptor-related protein. J Biol Chem 271: 30121-30125.

Fagan AM, Murphy BA, Patel SN, Kilbridge JF, Mobley WC, Bu G, Holtzman DM. 1998. Evidence for normal aging of the septo-hippocampal cholinergic system in $\mathrm{apoE}^{-/-}$ mice but impaired clearance of axonal degeneration products following injury. Exp Neurol 151: 314-325.

Fagan AM, Watson M, Parsadanian M, Bales KR, Paul SM, Holtzman DM. 2002. Human and murine apoE markedly influence $A \beta$ metabolism both prior and subsequent to plaque formation in a mouse model of Alzheimer's disease. Neurobiol Dis 9: 305-318.

Farrer LA, Cupples LA, Haines JL, Hyman B, Kukull WA, Mayeux R, Myers RH, Pericak-Vance MA, Risch N, van Duijn CM. 1997. Effects of age, sex, and ethnicity on the association between apolipoprotein $\mathrm{E}$ genotype and Alzheimer disease. A meta-analysis. APOE and Alzheimer Disease Meta Analysis Consortium. JAMA 278: 1349-1356.

Forster E, Bock HH, Herz J, Chai X, Frotscher M, Zhao S. 2010. Emerging topics in Reelin function. Eur J Neurosci 31: $1511-1518$.

Frotscher M. 2010. Role for Reelin in stabilizing cortical architecture. Trends Neurosci 33: 407-414.

Fryer JD, Taylor JW, DeMattos RB, Bales KR, Paul SM, Parsadanian M, Holtzman DM. 2003. Apolipoprotein E markedly facilitates age-dependent cerebral amyloid angiopathy and spontaneous hemorrhage in APP transgenic mice. J Neurosci 23: 7889-7896.

Fryer JD, Demattos RB, McCormick LM, O'Dell M A, Spinner ML, Bales KR, Paul SM, Sullivan PM, Parsadanian M, $\mathrm{Bu} \mathrm{G}$, et al. 2005a. The low density lipoprotein receptor regulates the level of central nervous system human and murine apolipoprotein $\mathrm{E}$ but does not modify amyloid plaque pathology in PDAPP mice. J Biol Chem 280: 25754-25759.

Fryer JD, Simmons K, Parsadanian M, Bales KR, Paul SM, Sullivan PM, Holtzman DM. 2005b. ApoE4 alters the 
D.M. Holtzman et al.

amyloid- $\beta$ 40:42 ratio and promotes the formation of cerebral amyloid angiopathy in an APP transgenic model. J Neurosci 25: 2803-2810.

Fuentealba RA, Barria MI, Lee J, Cam J, Araya C, Escudero CA, Inestrosa NC, Bronfman FC, Bu G, Marzolo MP. 2007. ApoER2 expression increases $A \beta$ production while decreasing Amyloid Precursor Protein (APP) endocytosis: Possible role in the partitioning of APP into lipid rafts and in the regulation of $\gamma$-secretase activity. Mol Neurodegener 2: 14 .

Gajera CR, Emich H, Lioubinski O, Christ A, Beckervordersandforth-Bonk R, Yoshikawa K, Bachmann S, Christensen EI, Gotz M, Kempermann G, et al. 2010. LRP2 in ependymal cells regulates BMP signaling in the adult neurogenic niche. J Cell Sci 123: 1922-1930.

Gimbel DA, Nygaard HB, Coffey EE, Gunther EC, Lauren J, Gimbel ZA, Strittmatter SM. 2010. Memory impairment in transgenic Alzheimer mice requires cellular prion protein. J Neurosci 30: 6367-6374.

Gong JS, Kobayashi M, Hayashi H, Zou K, Sawamura N, Fujita SC, Yanagisawa K, Michikawa M. 2002. Apolipoprotein $\mathrm{E}$ (ApoE) isoform-dependent lipid release from astrocytes prepared from human ApoE3 and ApoE4 knock-in mice. J Biol Chem 277: 29919-29926.

Gotthardt M, Trommsdorff M, Nevitt MF, Shelton J, Richardson JA, Stockinger W, Nimpf J, Herz J. 2000. Interactions of the low density lipoprotein receptor gene family with cytosolic adaptor and scaffold proteins suggest diverse biological functions in cellular communication and signal transduction. J Biol Chem 275: 25616-25624.

Greenberg SM, Rebeck GW, Vonsattel JPG, Gomez-Isla T, Hyman BT. 1995. Apolipoprotein E $\varepsilon 4$ and cerebral hemorrhage associated with amyloid angiopathy. Ann Neurol 38: 254-259.

Grehan S, Tse E, Taylor JM. 2001. Two distal downstream enhancers direct expression of the human apolipoprotein E gene to astrocytes in the brain. J Neurosci 21: 812-822.

Groc L, Choquet D, Stephenson FA, Verrier D, Manzoni OJ, Chavis P. 2007. NMDA receptor surface trafficking and synaptic subunit composition are developmentally regulated by the extracellular matrix protein Reelin. J Neurosci 27: $10165-10175$.

Haass C, Selkoe DJ. 2007. Soluble protein oligomers in neurodegeneration: Lessons from the Alzheimer's amyloid B-peptide. Nat Rev Mol Cell Biol 8: 101-112.

* Haass C, Kaether C, Sisodia S, Thinakaran G. 2011. Trafficking and proteolytic processing of APP. Cold Spring Harb Perspect Med doi: 10.1101/cshperspect.a006270.

Han X. 2007. Potential mechanisms contributing to sulfatide depletion at the earliest clinically recognizable stage of Alzheimer's disease: A tale of shotgun lipidomics. J Neurochem 103: 171-179.

Hardingham GE, Fukunaga Y, Bading H. 2002. Extrasynaptic NMDARs oppose synaptic NMDARs by triggering CREB shut-off and cell death pathways. Nat Neurosci 5: 405-414.

Harold D, Abraham R, Hollingworth P, Sims R, Gerrish A, Hamshere ML, Pahwa JS, Moskvina V, Dowzell K, Williams A, et al. 2009. Genome-wide association study identifies variants at CLU and PICALM associated with Alzheimer's disease. Nat Genet 41: 1088-1093.

Heinonen O, Lehtovirta M, Soininen H, Helisalmi S, Mannermaa A, Sorvari H, Kosunen O, Paljarvi L, Ryynanen M, Riekkinen PJ Sr. 1995. Alzheimer pathology of patients carrying apolipoprotein E $\varepsilon 4$ allele. Neurobiol Aging 16: 505-513.

Herz J. 2009. Apolipoprotein E receptors in the nervous system. Curr Opin Lipidol 20: 190-196.

Herz J, Beffert U. 2000. Apolipoprotein E receptors: Linking brain development and Alzheimer's disease. Nature Rev 1: 51-58.

Herz J, Chen Y. 2006. Reelin, lipoprotein receptors and synaptic plasticity. Nat Rev Neurosci 7: 850-859.

Herz J, Clouthier DE, Hammer RE. 1992. LDL receptorrelated protein internalizes and degrades uPA-PAI-1 complexes and is essential for embryo implantation. Cell 71: 411-421.

Herz J, Chen Y, Masiulis I, Zhou L. 2009. Expanding functions of lipoprotein receptors. J Lipid Res 50(Suppl): S287-S292.

Hiesberger T, Trommsdorff M, Howell BW, Goffinet A, Mumby MC, Cooper JA, Herz J. 1999. Direct binding of Reelin to VLDL receptor and ApoE receptor 2 induces tyrosine phosphorylation of disabled-1 and modulates tau phosphorylation. Neuron 24: 481-489.

Hirsch-Reinshagen V, Zhou S, Burgess BL, Bernier L, McIsaac SA, Chan JY, Tansley GH, Cohn JS, Hayden MR, Wellington CL. 2004. Deficiency of ABCA1 impairs apolipoprotein E metabolism in brain. J Biol Chem 279: 41197-41207.

Hirsch-Reinshagen V, Maia LF, Burgess BL, Blain JF, Naus KE, McIsaac SA, Parkinson PF, Chan JY, Tansley GH, Hayden MR, et al. 2005. The absence of ABCA1 decreases soluble ApoE levels but does not diminish amyloid deposition in two murine models of Alzheimer disease. J Biol Chem 280: 43243-43256.

Hoe HS, Wessner D, Beffert U, Becker AG, Matsuoka Y, Rebeck GW. 2005. F-spondin interaction with the apolipoprotein E receptor ApoEr2 affects processing of amyloid precursor protein. Mol Cell Biol 25: 9259-9268.

Hoe HS, Freeman J, Rebeck GW. 2006a. Apolipoprotein E decreases tau kinases and phospho-tau levels in primary neurons. Mol Neurodegen 1: 18.

Hoe HS, Pocivavsek A, Chakraborty G, Fu Z, Vicini S, Ehlers MD, Rebeck GW. 2006b. Apolipoprotein E receptor 2 interactions with the $N$-methyl-D-aspartate receptor. J Biol Chem 281: 3425-3431.

Hoe HS, Fu Z, Makarova A, Lee JY, Lu C, Feng L, PajooheshGanji A, Matsuoka Y, Hyman BT, Ehlers MD, et al. 2009. The effects of amyloid precursor protein on postsynaptic composition and activity. J Biol Chem 284: 8495-8506.

Holtzman DM, Pitas RE, Kilbridge J, Nathan B, Mahley RW, Bu G, Schwartz AL. 1995. LRP mediates apolipoprotein E-dependent neurite outgrowth in a CNS-derived neuronal cell line. Proc Natl Acad Sci 92: 9480-9484.

Holtzman DM, Bales KR, Tenkova T, Fagan AM, Parsadanian M, Sartorius LJ, Mackey B, Olney J, McKeel D, Wozniak D, et al. 2000a. Apolipoprotein E isoformdependent amyloid deposition and neuritic degeneration 
in a mouse model of Alzheimer's disease. Proc Natl Acad Sci 97: 2892-2897.

Holtzman DM, Fagan AM, Mackey B, Tenkova T, Sartorius L, Paul SM, Bales K, Ashe KH, Irizzary MC, Hyman BT. 2000b. ApoE facilitates neuritic and cerebrovascular plaque formation in the APPsw mouse model of Alzheimer's disease. Ann Neurol 47: 739-747.

Hone E, Martins IJ, Jeoung M, Ji TH, Gandy SE, Martins RN. 2005. Alzheimer's disease amyloid- $\beta$ peptide modulates apolipoprotein $\mathrm{E}$ isoform specific receptor binding. J Alzheimers Dis 7: 303-314.

Hoover BR, Reed MN, Su J, Penrod RD, Kotilinek LA, Grant MK, Pitstick R, Carlson GA, Lanier LM, Yuan LL, et al. 2010. Tau mislocalization to dendritic spines mediates synaptic dysfunction independently of neurodegeneration. Neuron 68: 1067-1081.

Howell BW, Gertler FB, Cooper JA. 1997. Mouse disabled (mDab1): A Src binding protein implicated in neuronal development. EMBO J 16: 121-132.

Hu X, Crick SL, Bu G, Frieden C, Pappu RV, Lee JM. 2009. Amyloid seeds formed by cellular uptake, concentration, and aggregation of the amyloid- $\beta$ peptide. Proc Natl Acad Sci 106: 20324-20329.

Huang SS, Ling TY, Tseng WF, Huang YH, Tang FM, Leal SM, Huang JS. 2003. Cellular growth inhibition by IGFBP-3 and TGF- $\beta 1$ requires LRP- 1 . FASEB $J$ 17: 2068-2081.

Irizarry MC, Cheung BS, Rebeck GW, Paul SM, Bales KR, Hyman BT. 2000. Apolipoprotein E affects the amount, form, and anatomical distribution of amyloid $\beta$-peptide deposition in homozygous $\mathrm{APP}(\mathrm{V} 717 \mathrm{~F})$ transgenic mice. Acta Neuropathol 100: 451-458.

Ito S, Ohtsuki S, Kamiie J, Nezu Y, Terasaki T. 2007. Cerebral clearance of human amyloid- $\beta$ peptide $(1-40)$ across the blood-brain barrier is reduced by self-aggregation and formation of low-density lipoprotein receptor-related protein-1 ligand complexes. J Neurochem 103: 24822490.

Ittner LM, Ke YD, Delerue F, Bi M, Gladbach A, van Eersel J, Wolfing H, Chieng BC, Christie MJ, Napier IA, et al. 2010. Dendritic function of tau mediates amyloid- $\beta$ toxicity in Alzheimer's disease mouse models. Cell 142: 387-397.

Jiang Q, Lee CY, Mandrekar S, Wilkinson B, Cramer P, Zelcer N, Mann K, Lamb B, Willson TM, Collins JL, et al. 2008. ApoE promotes the proteolytic degradation of A $\beta$. Neuron 58: 681-693.

Johnson EB, Hammer RE, Herz J. 2005. Abnormal development of the apical ectodermal ridge and polysyndactyly in Megf7-deficient mice. Hum Mol Genet 14: 3523-3538.

Kanekiyo T, Bu G. 2009. Receptor-associated protein interacts with amyloid- $\beta$ peptide and promotes its cellular uptake. J Biol Chem 284: 33352-33359.

Karner CM, Dietrich MF, Johnson EB, Kappesser N, Tennert C, Percin F, Wollnik B, Carroll TJ, Herz J. 2010. Lrp4 regulates initiation of ureteric budding and is crucial for kidney formation-A mouse model for CenaniLenz syndrome. PLoS One 5: e10418. doi: 10.1371/ journal.pone.0010418.

Kim J, Basak JM, Holtzman DM. 2009a. The role of apolipoprotein E in Alzheimer's disease. Neuron 63: 287-303.
Kim J, Castellano JM, Jiang H, Basak JM, Parsadanian M Pham V, Mason SM, Paul SM, Holtzman DM. 2009b. Overexpression of low-density lipoprotein receptor in the brain markedly inhibits amyloid deposition and increases extracellular $A \beta$ clearance. Neuron 64: 632644.

Kinoshita A, Whelan CM, Smith CJ, Mikhailenko I, Rebeck GW, Strickland DK, Hyman BT. 2001. Demonstration by fluorescence resonance energy transfer of two sites of interaction between the low-density lipoprotein receptor-related protein and the amyloid precursor protein: Role of the intracellular adapter protein Fe65. J Neurosci 21: 8354-8361.

Kocherhans S, Madhusudan A, Doehner J, Breu KS, Nitsch RM, Fritschy JM, Knuesel I. 2010. Reduced Reelin expression accelerates amyloid-beta plaque formation and tau pathology in transgenic Alzheimer's disease mice. J Neurosci 30: 9228-9240.

Koistinaho M, Lin S, Wu X, Esterman M, Koger D, Hanson J, Higgs R, Liu F, Malkani S, Bales KR, et al. 2004. Apolipoprotein $\mathrm{E}$ promotes astrocyte colocalization and degradation of deposited amyloid- $\beta$ peptides. Nat Med 10: 719-726.

Koldamova R, Staufenbiel M, Lefterov I. 2005a. Lack of ABCA1 considerably decreases brain ApoE level and increases amyloid deposition in APP23 mice. J Biol Chem 280: 43224-43235.

Koldamova RP, Lefterov IM, Staufenbiel M, Wolfe D, Huang S, Glorioso JC, Walter M, Roth MG, Lazo JS. 2005b. The liver X receptor ligand T0901317 decreases amyloid $\beta$ production in vitro and in a mouse model of Alzheimer's disease. J Biol Chem 280: 4079-4088.

Korwek KM, Trotter JH, Ladu MJ, Sullivan PM, Weeber EJ. 2009. ApoE isoform-dependent changes in hippocampal synaptic function. Molec Neurodegen 4: 21.

Kounnas MZ, Moir RD, Rebeck GW, Bush AI, Argraves WS, Tanzi RE, Hyman BT, Strickland DK. 1995. LDLreceptor-related protein, a multifunctional apoE receptor, binds secreted $\beta$-amyloid precursor protein and mediates its degradation. Cell 82: 331-340.

Kowal RC, Herz J, Weisgraber KH, Mahley RW, Brown MS, Goldstein JL. 1990. Opposing effects of apolipoproteins E and $\mathrm{C}$ on lipoprotein binding to low density lipoprotein receptor-related protein. J Biol Chem 265: 10771-10779.

Lacor PN, Buniel MC, Chang L, Fernandez SJ, Gong Y, Viola KL, Lambert MP, Velasco PT, Bigio EH, Finch CE, et al 2004. Synaptic targeting by Alzheimer's-related amyloid $\beta$ oligomers. J Neurosci 24: 10191-10200.

LaDu MJ, Falduto MT, Manelli AM, Reardon CA, Getz GS, Frail DE. 1994. Isoform-specific binding of apolipoprotein E to $\beta$-amyloid. J Biol Chem 269: 23404-23406.

LaDu MJ, Gilligan SM, Lukens SR, Cabana VG, Reardon CA, Van Eldik LJ, Holtzman DM. 1998. Nascent astrocyte particles differ from lipoproteins in CSF. $J$ Neurochem 70: 2070-2081.

Lambert MP, Barlow AK, Chromy BA, Edwards C, Freed R, Liosatos M, Morgan TE, Rozovsky I, Trommer B, Viola KL, et al. 1998. Diffusible, nonfibrillar ligands derived from $A \beta 1-42$ are potent central nervous system neurotoxins. Proc Natl Acad Sci 95: 6448-6453.

Lambert JC, Heath S, Even G, Campion D, Sleegers K, Hiltunen M, Combarros O, Zelenika D, Bullido MJ, 
D.M. Holtzman et al.

Tavernier B, et al. 2009. Genome-wide association study identifies variants at CLU and CR1 associated with Alzheimer's disease. Nat Genet 41: 1094-1099.

Lesne S, Koh MT, Kotilinek L, Kayed R, Glabe CG, Yang A, Gallagher M, Ashe KH. 2006. A specific amyloid- $\beta$ protein assembly in the brain impairs memory. Nature 440: 352-357.

Lillis AP, Van Duyn LB, Murphy-Ullrich JE, Strickland DK. 2008. LDL receptor-related protein 1: Unique tissuespecific functions revealed by selective gene knockout studies. Physiol Rev 88: 887-918.

Liu Q, Zerbinatti CV, Zhang J, Hoe HS, Wang B, Cole SL, Herz J, Muglia L, Bu G. 2007. Amyloid precursor protein regulates brain apolipoprotein $\mathrm{E}$ and cholesterol metabolism through lipoprotein receptor LRP1. Neuron 56: $66-78$.

Loukinova E, Ranganathan S, Kuznetsov S, Gorlatova N, Migliorini MM, Loukinov D, Ulery PG, Mikhailenko I, Lawrence DA, Strickland DK. 2002. Platelet-derived growth factor (PDGF)-induced tyrosine phosphorylation of the low density lipoprotein receptor-related protein (LRP). Evidence for integrated co-receptor function between LRP and the PDGF. J Biol Chem 277: 15499-15506.

Ma J, Yee A, Brewer HB, Das S, Potter H. 1994. Amyloidassociated proteins $\alpha$-1-antichymotrypsin and apolipoprotein E promote assembly of Alzheimer beta-protein into filaments. Nature 372: 92-94.

Mahley RW. 1988. Apolipoprotein E: Cholesterol transport protein with expanding role in cell biology. Science $\mathbf{2 4 0}$ $622-630$.

Mahley RW, Rall SC Jr. 2000. Apolipoprotein E: Far more than a lipid transport protein. Annu Rev Genomics Hum Genet 1: 507-537.

Mahley RW, Huang Y, Weisgraber KH. 2006. Putting cholesterol in its place: ApoE and reverse cholesterol transport. J Clin Invest 116: 1226-1229.

Mandrekar S, Jiang Q, Lee CY, Koenigsknecht-Talboo J, Holtzman DM, Landreth GE. 2009. Microglia mediate the clearance of soluble $A \beta$ through fluid phase macropinocytosis. J Neurosci 29: 4252-4262.

Masiulis I, Quill TA, Burk RF, Herz J. 2009. Differential functions of the Apoer2 intracellular domain in selenium uptake and cell signaling. Biol Chem 390: 67-73.

Masliah E, Mallory M, Ge N, Alford M, Veinbergs I, Roses AD. 1995. Neurodegeneration in the central nervous system of apoE-deficient mice. Exp Neurol 136: 107-122.

Matsuki T, Pramatarova A, Howell BW. 2008. Reduction of Crk and CrkL expression blocks reelin-induced dendritogenesis. J Cell Sci 121: 1869-1875.

Mauch DH, Nagler K, Schumacher S, Goritz C, Muller EC, Otto A, Pfrieger FW. 2001. CNS synaptogenesis promoted by glia-derived cholesterol. Science 294: 1354-1357.

May P, Rohlmann A, Bock HH, Zurhove K, Marth JD, Schomburg ED, Noebels JL, Beffert U, Sweatt JD, Weeber EJ, et al. 2004. Neuronal LRP1 functionally associates with postsynaptic proteins and is required for normal motor function in mice. Mol Cell Biol 24: 8872-8883.

McLaughlin L, Zhu G, Mistry M, Ley-Ebert C, Stuart WD, Florio CJ, Groen PA, Witt SA, Kimball TR, Witte DP, et al. 2000. Apolipoprotein J/clusterin limits the severity of murine autoimmune myocarditis. J Clin Invest 106: 1105-1113.

Michikawa M, Fan QW, Isobe I, Yanagisawa K. 2000. Apolipoprotein E exhibits isoform-specific promotion of lipid efflux from astrocytes and neurons in culture. J Neurochem 74: 1008-1016.

Morris JC, Roe CM, Xiong C, Fagan AM, Goate AM, Holtzman DM, Mintun MA. 2010. APOE predicts amyloidbeta but not tau Alzheimer pathology in cognitively normal aging. Ann Neurol 67: 122-131.

* Mucke L, Selkoe DJ. 2011. Neurotoxicity of amyloid $\beta$-protein: Synaptic and network dysfunction. Cold Spring Harb Perspect Med doi: 10.1101/cshperspect.a006338.

Mudher A, Shepherd D, Newman TA, Mildren P, Jukes JP, Squire A, Mears A, Drummond JA, Berg S, MacKay D, et al. 2004. GSK-3 $\beta$ inhibition reverses axonal transport defects and behavioural phenotypes in Drosophila. Mol Psychiatry 9: 522-530.

Namba Y, Tomonaga M, Kawasaki H, Otomo E, Ikeda K. 1991. Apolipoprotein E immunoreactivity in cerebral amyloid deposits and neurofibrillary tangles in Alzheimer's disease kuru plaque amyloid in CreutzfeldtJacob disease. Brain Res 541: 163-166.

Narita N, Holtzman DM, Schwartz AL, Bu G. 1997. $\alpha_{2}$-Macroglobulin complexes with and mediates the endocytosis of $\beta$-amyloid peptide via cell surface low-density lipoprotein receptor-related protein. J Neurochem 69: 1904-1911.

Narita M, Holtzman DM, Fagan AM, LaDu MJ, Yu L, Han X, Gross RW, Bu G, Schwartz AL. 2002. Cellular catabolism of lipid poor apolipoprotein E via cell surface LDL receptor-related protein. J Biochem 132: 743-749.

Nathan BP, Bellosta S, Sanan DA, Weisgraber KH, Mahley RW, Pitas RE. 1994. Differential effects of apolipoproteins E3 and E4 on neuronal growth in vitro. Science 264: $850-852$.

Nickerson DA, Taylor SL, Fullerton SM, Weiss KM, Clark AG, Stengard JH, Salomaa V, Boerwinkle E, Sing CF. 2000. Sequence diversity and large-scale typing of SNPs in the human apolipoprotein E gene. Genome Res 10: 1532-1545.

Niu S, Renfro A, Quattrocchi CC, Sheldon M, D'Arcangelo G. 2004. Reelin promotes hippocampal dendrite development through the VLDLR/ApoER2-Dab1 pathway. Neuron 41: 71-84.

Niu S, Yabut O, D’Arcangelo G. 2008. The Reelin signaling pathway promotes dendritic spine development in hippocampal neurons. J Neurosci 28: 10339-10348.

Nygaard HB, Strittmatter SM. 2009. Cellular prion protein mediates the toxicity of $\beta$-amyloid oligomers: Implications for Alzheimer disease. Arch Neurol 66: 1325-1328.

Ohkubo N, Lee YD, Morishima A, Terashima T, Kikkawa S, Tohyama M, Sakanaka M, Tanaka J, Maeda N, Vitek MP, et al. 2003. Apolipoprotein E and Reelin ligands modulate tau phosphorylation through an apolipoprotein $\mathrm{E}$ receptor/disabled-1/glycogen synthase kinase- $3 \beta$ cascade. FASEB J 17: 295-297.

Palop JJ, Mucke L. 2010. Amyloid- $\beta$-induced neuronal dysfunction in Alzheimer's disease: From synapses toward neural networks. Nat Neurosci 13: 812-818. 
Palop JJ, Chin J, Roberson ED, Wang J, Thwin MT, Bien-Ly N, Yoo J, Ho KO, Yu GQ, Kreitzer A, et al. 2007. Aberrant excitatory neuronal activity and compensatory remodeling of inhibitory hippocampal circuits in mouse models of Alzheimer's disease. Neuron 55: 697-711.

Peters MM, Hill KE, Burk RF, Weeber EJ. 2006. Altered hippocampus synaptic function in selenoprotein $\mathrm{P}$ deficient mice. Mol Neurodegener 1: 12.

Pfrieger FW. 2003. Cholesterol homeostasis and function in neurons of the central nervous system. Cell Mol Life Sci 60: $1158-1171$.

Pietrzik CU, Yoon IS, Jaeger S, Busse T, Weggen S, Koo EH 2004. FE65 constitutes the functional link between the low-density lipoprotein receptor-related protein and the amyloid precursor protein. J Neurosci 24: 4259-4265.

Pitas RE, Boyles JK, Lee SH, Foss D, Mahley RW. 1987. Astrocytes synthesize apolipoprotein $\mathrm{E}$ and metabolize apolipoprotein E-containing lipoproteins. Biochim Biophys Acta 917: 148-161.

Poirier J. 2003. Apolipoprotein E and cholesterol metabolism in the pathogenesis and treatment of Alzheimer's disease. Trends Mol Med 9: 94-101.

Pujadas L, Gruart A, Bosch C, Delgado L, Teixeira CM, Rossi D, de Lecea L, Martinez A, Delgado-Garcia JM, Soriano E. 2010. Reelin regulates postnatal neurogenesis and enhances spine hypertrophy and long-term potentiation. J Neurosci 30: 4636-4649.

Puzzo D, Privitera L, Leznik E, Fa M, Staniszewski A, Palmeri A, Arancio O. 2008. Picomolar amyloid- $\beta$ positively modulates synaptic plasticity and memory in hippocampus. J Neurosci 28: 14537-14545.

Qiu S, Zhao LF, Korwek KM, Weeber EJ. 2006. Differential reelin-induced enhancement of NMDA and AMPA receptor activity in the adult hippocampus. $J$ Neurosci 26: $12943-12955$.

Rapp A, Gmeiner B, Huttinger M. 2006. Implication of apoE isoforms in cholesterol metabolism by primary rat hippocampal neurons and astrocytes. Biochimie 88: 473-483.

Rebeck GW, Reiter JS, Strickland DK, Hyman BT. 1993. Apolipoprotein E in sporadic Alzheimer's disease: Allelic variation and receptor interactions. Neuron 11: 575-580.

Rebeck GW, Harr SD, Strickland DK, Hyman BT. 1995. Multiple, diverse senile plaque-associated proteins are ligands of an apolipoprotein receptor, the $\alpha 2$-macroglobulin receptor/low-density-lipoprotein receptor-related protein. Ann Neurol 37: 211-217.

Reiman EM, Chen K, Liu X, Bandy D, Yu M, Lee W, Ayutyanont N, Keppler J, Reeder SA, Langbaum JB, et al. 2009. Fibrillar amyloid- $\beta$ burden in cognitively normal people at 3 levels of genetic risk for Alzheimer's disease. Proc Natl Acad Sci 106: 6820-6825.

Renner M, Lacor PN, Velasco PT, Xu J, Contractor A, Klein WL, Triller A. 2010. Deleterious effects of amyloid $\beta$ oligomers acting as an extracellular scaffold for mGluR5. Neuron 66: 739-754.

Roberson ED, Scearce-Levie K, Palop JJ, Yan F, Cheng IH, Wu T, Gerstein H, Yu GQ, Mucke L. 2007. Reducing endogenous tau ameliorates amyloid $\beta$-induced deficits in an Alzheimer's disease mouse model. Science 316: $750-754$.
Roberson ED, Halabisky B, Yoo JW, Yao J, Chin J, Yan F, Wu T, Hamto P, Devidze N, Yu GQ, et al. 2011. Amyloid- $\beta$ / Fyn-induced synaptic, network, and cognitive impairments depend on tau levels in multiple mouse models of Alzheimer's disease. J Neurosci 31: 700-711.

Rogaeva E, Meng Y, Lee JH, Gu Y, Kawarai T, Zou F, Katayama T, Baldwin CT, Cheng R, Hasegawa H, et al. 2007. The neuronal sortilin-related receptor SORL1 is genetically associated with Alzheimer disease. Nat Genet 39: $168-177$.

Ronicke R, Mikhaylova M, Ronicke S, Meinhardt J, Schroder UH, Fandrich M, Reiser G, Kreutz MR, Reymann KG. 2010. Early neuronal dysfunction by amyloid $\beta$ oligomers depends on activation of NR2B-containing NMDA receptors. Neurobiol Aging doi: 10.1016/ j.neurobiolaging.2010.01.011.

Rust MB, Gurniak CB, Renner M, Vara H, Morando L, Gorlich A, Sassoe-Pognetto M, Banchaabouchi MA, Giustetto M, Triller A, et al. 2010. Learning, AMPA receptor mobility and synaptic plasticity depend on n-cofilinmediated actin dynamics. EMBO J 29: 1889-1902.

Sadowski MJ, Pankiewicz J, Scholtzova H, Mehta PD, Prelli F, Quartermain D, Wisniewski T. 2006. Blocking the apolipoprotein $\mathrm{E} /$ amyloid- $\beta$ interaction as a potential therapeutic approach for Alzheimer's disease. Proc Natl Acad Sci 103: 18787-18792.

Sagare A, Deane R, Bell RD, Johnson B, Hamm K, Pendu R, Marky A, Lenting PJ, Wu Z, Zarcone T, et al. 2007. Clearance of amyloid- $\beta$ by circulating lipoprotein receptors. Nat Med 13: 1029-1031.

* Saido T, Leissring MA. 2011. Proteolytic degradation of amyloid $\beta$-protein. Cold Spring Harb Perspect Med doi: 10.1011/cshperspect.a006379.

Salter MW, Kalia LV. 2004. Src kinases: A hub for NMDA receptor regulation. Nat Rev Neurosci 5: 317-328.

Sanan DA, Weisgraber KH, Russel SJ, Mahley RW, Huang D, Saunders A, Schmechel D, Wisniewksi T, Frangione B, Roses B, et al. 1994. Apolipoprotein E associates with $\beta$ amyloid peptide of Alzheimer's disease to form novel monofibrils. J Clin Invest 94: 860-869.

Schaefer EJ, Heaton WH, Wetzel MG, Brewer HB Jr. 1982. Plasma apolipoprotein A-1 absence associated with a marked reduction of high density lipoproteins and premature coronary artery disease. Arteriosclerosis 2: 16-26.

Scherzer CR, Offe K, Gearing M, Rees HD, Fang G, Heilman CJ, Schaller C, Bujo H, Levey AI, Lah JJ. 2004. Loss of apolipoprotein E receptor LR11 in Alzheimer disease. Arch Neurol 61: 1200-1205.

Schmechel DE, Saunders AM, Strittmattter WJ, Crain BJ, Hulette CM, Joo SH, Pericak-Vance MA, Goldgaber D, Roses AD. 1993. Increased amyloid $\beta$-peptide deposition in cerebral cortex as a consequence of apolipoprotein genotype in late-onset Alzheimer disease. Proc Natl Acad Sci 90: 9649-9653.

Shankar GM, Bloodgood BL, Townsend M, Walsh DM, Selkoe DJ, Sabatini BL. 2007. Natural oligomers of the Alzheimer amyloid- $\beta$ protein induce reversible synapse loss by modulating an NMDA-type glutamate receptordependent signaling pathway. J Neurosci 27: 2866-2875.

Shankar GM, Li S, Mehta TH, Garcia-Munoz A, Shepardson NE, Smith I, Brett FM, Farrell MA, Rowan MJ, Lemere $\mathrm{CA}$, et al. 2008. Amyloid- $\beta$ protein dimers isolated 
D.M. Holtzman et al.

directly from Alzheimer's brains impair synaptic plasticity and memory. Nat Med 14: 837-842.

Sheldon M, Rice DS, D'Arcangelo G, Yoneshima H, Nakajima K, Mikoshiba K, Howell BW, Cooper JA, Goldowitz D, Curran T. 1997. Scrambler and yotari disrupt the disabled gene and produce a reeler-like phenotype in mice. Nature 389: 730-733.

Shibata M, Yamada S, Kumar SR, Calero M, Bading J, Frangione B, Holtzman DM, Miller CA, Strickland DK, Ghiso J, et al. 2000. Clearance of Alzheimer's amyloid- $\beta 1-40$ peptide from brain by LDL receptor-related protein-1 at the blood-brain barrier. J Clin Invest 106: 1489-1499.

Shu T, Ayala R, Nguyen MD, Xie Z, Gleeson JG, Tsai LH. 2004. Ndell operates in a common pathway with LIS1 and cytoplasmic dynein to regulate cortical neuronal positioning. Neuron 44: 263-277.

Sinagra M, Verrier D, Frankova D, Korwek KM, Blahos J, Weeber EJ, Manzoni OJ, Chavis P. 2005. Reelin, very-low-density lipoprotein receptor, and apolipoprotein E receptor 2 control somatic NMDA receptor composition during hippocampal maturation in vitro. $J$ Neurosci 25: 6127-6136.

Snyder EM, Nong Y, Almeida CG, Paul S, Moran T, Choi EY, Nairn AC, Salter MW, Lombroso PJ, Gouras GK, et al. 2005. Regulation of NMDA receptor trafficking by amyloid- $\beta$. Nat Neurosci 8: 1051-1058.

Sorci-Thomas M, Prack MM, Dashti N, Johnson F, Rudel LL, Williams DL. 1988. Apolipoprotein (apo) A-I production and mRNA abundance explain plasma apoA-I and high density lipoprotein differences between two nonhuman primate species with high and low susceptibilities to diet-induced hypercholesterolemia. J Biol Chem 263: 5183-5189.

Stockinger W, Brandes C, Fasching D, Hermann M, Gotthardt M, Herz J, Schneider WJ, Nimpf J. 2000. The reelin receptor ApoER2 recruits JNK-interacting proteins-1 and -2. J Biol Chem 275: 25625-25632.

Stolt PC, Chen Y, Liu P, Bock HH, Blacklow SC, Herz J. 2005. Phosphoinositide binding by the disabled-1 PTB domain is necessary for membrane localization and Reelin signal transduction. J Biol Chem 280: 9671-9677.

Strasser V, Fasching D, Hauser C, Mayer H, Bock HH, Hiesberger T, Herz J, Weeber EJ, Sweatt JD, Pramatarova A, et al. 2004. Receptor clustering is involved in Reelin signaling. Mol Cell Biol 24: 1378-1386.

Strittmatter WJ, Saunders AM, Schmechel D, Pericak-Vance M, Enghild J, Salvesen GS, Roses AD. 1993a. Apolipoprotein E: High avidity binding to $\beta$-amyloid and increased frequency of type 4 allele in late-onset familial Alzheimer disease. Proc Natl Acad Sci 90: 1977-1981.

Strittmatter WJ, Weisgraber KH, Huang DY, Dong L-Y, Salvesen GS, Pericak-Vance M, Schmechel D, Saunders AM, Goldgaber D, Roses AD. 1993b. Binding of human apolipoprotein $\mathrm{E}$ to synthetic amyloid $\beta$ peptide: Isoformspecific effects and implications for late-onset Alzheimer disease. Proc Natl Acad Sci 90: 8098-8102.

Sunderland T, Mirza N, Putnam KT, Linker G, Bhupali D, Durham R, Soares H, Kimmel L, Friedman D, Bergeson $J$, et al. 2004. Cerebrospinal fluid $\beta$-amyloid ${ }_{1-42}$ and tau in control subjects at risk for Alzheimer's disease: The effect of APOE $\varepsilon 4$ allele. Biol Psychiatry 56: 670-676.
Sydow A, Van der Jeugd A, Zheng F, Ahmed T, Balschun D, Petrova O, Drexler D, Zhou L, Rune G, Mandelkow E, et al. 2011. Tau-induced defects in synaptic plasticity, learning, and memory are reversible in transgenic mice after switching off the toxic tau mutant. J Neurosci 31: 2511-2525.

Tamamizu-Kato S, Cohen JK, Drake CB, Kosaraju MG, Drury J, Narayanaswami V. 2008. Interaction with amyloid $\beta$ peptide compromises the lipid binding function of apolipoprotein E. Biochemistry 47: 5225-5234.

Terrand J, Bruban V, Zhou L, Gong W, El Asmar Z, May P, Zurhove K, Haffner P, Philippe C, Woldt E, et al. 2009. LRP1 controls intracellular cholesterol storage and fatty acid synthesis through modulation of Wnt signaling. J Biol Chem 284: 381-388.

Tiraboschi P, Hansen LA, Masliah E, Alford M, Thal LJ, Corey-Bloom J. 2004. Impact of APOE genotype on neuropathologic and neurochemical markers of Alzheimer disease. Neurology 62: 1977-1983.

Tissir F, Goffinet AM. 2003. Reelin and brain development. Nat Rev Neurosci 4: 496-505.

Tokuda T, Calero M, Matsubara E, Vidal R, Kumar A, Permanne B, Zlokovic B, Smith JD, Ladu MJ, Rostagno A, et al. 2000. Lipidation of apolipoprotein $E$ influences its isoform-specific interaction with Alzheimer's amyloid $\beta$ peptides. Biochem J 348: 359-365.

Townsend M, Shankar GM, Mehta T, Walsh DM, Selkoe DJ. 2006. Effects of secreted oligomers of amyloid $\beta$-protein on hippocampal synaptic plasticity: A potent role for trimers. J Physiol 572: 477-492.

Trommsdorff M, Borg JP, Margolis B, Herz J. 1998. Interaction of cytosolic adaptor proteins with neuronal apolipoprotein E receptors and the amyloid precursor protein. J Biol Chem 273: 33556-33560.

Trommsdorff M, Gotthardt M, Hiesberger T, Shelton J, Stockinger W, Nimpf J, Hammer RE, Richardson JA Herz J. 1999. Reeler/Disabled-like disruption of neuronal migration in knockout mice lacking the VLDL receptor and ApoE receptor 2. Cell 97: 689-701.

Ulery PG, Beers J, Mikhailenko I, Tanzi RE, Rebeck GW, Hyman BT, Strickland DK. 2000. Modulation of $\beta$-amyloid precursor protein processing by the low density lipoprotein receptor-related protein (LRP). Evidence that LRP contributes to the pathogenesis of Alzheimer's disease. J Biol Chem 275: 7410-7415.

Van Uden E, Mallory M, Ieinbergs I, Alford M, Rockenstein E, Masliah E. 2002. Increased extracellular amyloid deposition and neurodegeneration in human amyloid precursor protein transgenic mice deficient in receptorassociated protein. J Neurosci 22: 9298-9304.

Vazquez-Higuera JL, Mateo I, Sanchez-Juan P, RodriguezRodriguez E, Pozueta A, Infante J, Berciano J, Combarros O. 2009. Genetic interaction between tau and the apolipoprotein E receptor LRP1 Increases Alzheimer's disease risk. Dement Geriat Cogn Disord 28: 116-120.

Wahrle SE, Jiang H, Parsadanian M, Hartman RE, Bales KR, Paul SM, Holtzman DM. 2005. Deletion of Abcal increases $\mathrm{A} \beta$ deposition in the PDAPP transgenic mouse model of Alzheimer disease. J Biol Chem 280: 4323643242.

Wahrle SE, Jiang H, Parsadanian M, Kim J, Li A, Knoten A, Jain S, Hirsch-Reinshagen V, Wellington CL, Bales KR, 
et al. 2008. Overexpression of ABCA1 reduces amyloid deposition in the PDAPP mouse model of Alzheimer disease. J Clin Invest 118: 671-682.

Walsh DM, Klyubin I, Fadeeva JV, Cullen WK, Anwyl R, Wolfe MS, Rowan MJ, Selkoe DJ. 2002. Naturally secreted oligomers of amyloid $\beta$ protein potently inhibit hippocampal long-term potentiation in vivo. Nature 416: 535-539.

Weeber EJ, Beffert U, Jones C, Christian JM, Forster E, Sweatt JD, Herz J. 2002. Reelin and ApoE receptors cooperate to enhance hippocampal synaptic plasticity and learning. J Biol Chem 277: 39944-39952.

Willnow TE, Hilpert J, Armstrong SA, Rohlmann A, Hammer RE, Burns DK, Herz J. 1996. Defective forebrain development in mice lacking gp330/megalin. Proc Natl Acad Sci 93: 8460-8464.

Wisniewski T, Frangione B. 1992. Apolipoprotein E: A pathological chaperone protein in patients with cerebral and systemic amyloid. Neurosci Lett 135: 235-238.

Wisniewski T, Castano EM, Golabek A, Vogel T, Frangione B. 1994. Acceleration of Alzheimer's fibril formation by apolipoprotein E in vitro. Am J Pathol 145: 10301035.

Wood SJ, Chan W, Wetzel R. 1996. Seeding of A fibril formation is inhibited by all three isotypes of apolipoprotein E. Biochemistry 35: 12623-12628.

Xu P-T, Schmechel D, Qiu H-L, Herbstreith M, RothrockChristian T, Eyster M, Roses AD, Gilbert JR. 1999. Sialylated human apolipoprotein E (apoEs) is preferentially associated with neuron-enriched cultures from APOE transgenic mice. Neurobiol Dis 6: 63-75.

Xu Q, Bernardo A, Walker D, Kanegawa T, Mahley RW, Huang Y. 2006. Profile and regulation of apolipoprotein $\mathrm{E}$ (ApoE) expression in the CNS in mice with targeting
Apolipoprotein E and Apolipoprotein E Receptors

of green fluorescent protein gene to the ApoE locus. J Neurosci 26: 4985-4994.

Yang D-S, Smith JD, Zhou Z, Gandy S, Martins RN. 1997. Characterization of the binding of amyloid- $\beta$ peptide to cell culture-derived native apolipoprotein E2, E3, and E4 isoforms and to isoforms from human plasma. J Neurochem 68: 721-725.

Yang DS, Small DH, Seydel U, Smith JD, Hallmayer J, Gandy SE, Martins RN. 1999. Apolipoprotein E promotes the binding and uptake of $\beta$-amyloid into Chinese hamster ovary cells in an isoform-specific manner. Neuroscience 90: $1217-1226$.

Zerbinatti CV, Wozniak DF, Cirrito J, Cam JA, Osaka H, Bales KR, Zhuo M, Paul SM, Holtzman DM, Bu G. 2004. Increased soluble amyloid- $\beta$ peptide and memory deficits in amyloid model mice overexpressing the lowdensity lipoprotein receptor-related protein. Proc Natl Acad Sci 101: 1075-1080.

Zerbinatti CV, Wahrle SE, Kim H, Cam JA, Bales K, Paul SM, Holtzman DM, Bu G. 2006. Apolipoprotein E and low density lipoprotein receptor-related protein facilitate intraneuronal $A \beta 42$ accumulation in amyloid model mice. J Biol Chem 281: 36180-36186.

Zhuo M, Holtzman DM, Li Y, Osaka H, DeMaro J, Jacquin M, Bu G. 2000. Role of tissue plasminogen activator receptor LRP in hippocampal long-term potentiation. J Neurosci 20: 542-549.

Zlokovic BV. 2008. The blood-brain barrier in health and chronic neurodegenerative disorders. Neuron 57: $178-$ 201.

Zurhove K, Nakajima C, Herz J, Bock HH, May P. 2008. $\gamma$-secretase limits the inflammatory response through the processing of LRP1. Sci Signal 1: ra15. 


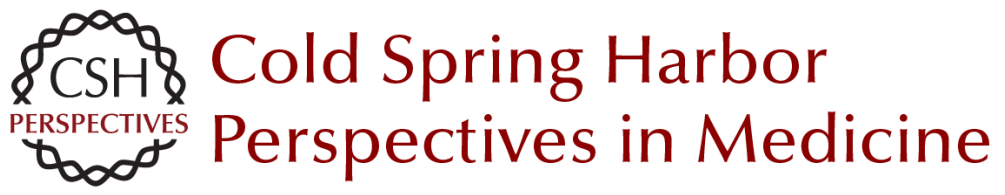

\section{Apolipoprotein E and Apolipoprotein E Receptors: Normal Biology and Roles in Alzheimer Disease}

David M. Holtzman, Joachim Herz and Guojun Bu

Cold Spring Harb Perspect Med 2012; doi: 10.1101/cshperspect.a006312 originally published online January 10, 2012

Subject Collection The Biology of Alzheimer Disease

Animal Models of Alzheimer Disease

Frank M. LaFerla and Kim N. Green

Neurovascular Dysfunction and Faulty Amyloid $\beta$

-Peptide Clearance in Alzheimer Disease

Abhay P. Sagare, Robert D. Bell and Berislav V. Zlokovic

Treatment Strategies Targeting Amyloid $\beta$-Protein Dale Schenk, Guriqbal S. Basi and Menelas N. Pangalos

The Ubiquitin-Proteasome System and the Autophagic-Lysosomal System in Alzheimer Disease

Yasuo Ihara, Maho Morishima-Kawashima and Ralph Nixon

Neurotoxicity of Amyloid $\beta$-Protein: Synaptic and Network Dysfunction

Lennart Mucke and Dennis J. Selkoe

Proteolytic Degradation of Amyloid $\beta$-Protein Takaomi Saido and Malcolm A. Leissring

Brain Imaging in Alzheimer Disease

Keith A. Johnson, Nick C. Fox, Reisa A. Sperling, et al.

Symptomatic and Nonamyloid/Tau Based Pharmacologic Treatment for Alzheimer Disease Paul S. Aisen, Jeffrey Cummings and Lon S. Schneider
Alzheimer Disease in 2020

David M. Holtzman, Eckhard Mandelkow and

Dennis J. Selkoe

The Genetics of Alzheimer Disease Rudolph E. Tanzi

Fluid Biomarkers in Alzheimer Disease

Kaj Blennow, Henrik Zetterberg and Anne M. Fagan

Epidemiology of Alzheimer Disease

Richard Mayeux and Yaakov Stern

\section{Biochemistry and Cell Biology of Tau Protein in} Neurofibrillary Degeneration

Eva-Maria Mandelkow and Eckhard Mandelkow

Biochemistry of Amyloid $\beta$-Protein and Amyloid

Deposits in Alzheimer Disease

Colin L. Masters and Dennis J. Selkoe

The Neuropsychological Profile of Alzheimer

Disease

Sandra Weintraub, Alissa H. Wicklund and David P.

Salmon

Apolipoprotein E and Apolipoprotein E Receptors: Normal Biology and Roles in Alzheimer Disease David M. Holtzman, Joachim Herz and Guojun Bu

For additional articles in this collection, see http://perspectivesinmedicine.cshlp.org/cgi/collection/ 